\title{
Polymer- and Hybrid-Based Biomaterials for Interstitial, Connective, Vascular, Nerve, Visceral and Musculoskeletal Tissue Engineering
}

\author{
Anatolii Abalymov* * Bogdan Parakhonskiy ${ }^{(1)}$ and Andre G. Skirtach * \\ Department of Biotechnology, Faculty of Bioscience Engineering, Ghent University, 9000 Ghent, Belgium \\ * Correspondence: anatolii.abalymov@gmail.com (A.A.); Andre.Skirtach@ugent.be (A.G.S.)
}

Received: 6 December 2019; Accepted: 3 March 2020; Published: 9 March 2020

\begin{abstract}
In this review, materials based on polymers and hybrids possessing both organic and inorganic contents for repairing or facilitating cell growth in tissue engineering are discussed. Pure polymer based biomaterials are predominantly used to target soft tissues. Stipulated by possibilities of tuning the composition and concentration of their inorganic content, hybrid materials allow to mimic properties of various types of harder tissues. That leads to the concept of "one-matches-all" referring to materials possessing the same polymeric base, but different inorganic content to enable tissue growth and repair, proliferation of cells, and the formation of the ECM (extra cellular matrix). Furthermore, adding drug delivery carriers to coatings and scaffolds designed with such materials brings additional functionality by encapsulating active molecules, antibacterial agents, and growth factors. We discuss here materials and methods of their assembly from a general perspective together with their applications in various tissue engineering sub-areas: interstitial, connective, vascular, nervous, visceral and musculoskeletal tissues. The overall aims of this review are two-fold: (a) to describe the needs and opportunities in the field of bio-medicine, which should be useful for material scientists, and (b) to present capabilities and resources available in the area of materials, which should be of interest for biologists and medical doctors.
\end{abstract}

Keywords: tissue engineering; interstitial; connective; vascular; nervous; visceral; musculoskeletal; polymers; hybrid; hydrogels; layer-by-layer; cells

\section{Introduction}

Except for the gut epithelium [1], cornea [2], skin [3], and liver [4], regeneration of adult tissue after an injury or degeneration is is an inefficient process. This is addressed by designing and applying innovative biomaterials targeting regeneration of tissues. Although promising data have been obtained in laboratories, some hurdles limiting the clinical translation of implants still remain including cell survival, migration, and integration [5]. Polymer-based coatings perfectly fill the niche of soft-tissue repair, because of the similarity between their mechanical, physico-chemical, and physiological properties and those of tissue.

There are different methods of assembling polymers into coatings and scaffolds. These include, for example, hydrogels, layer-by-layer (LbL), Langmuir-Blodgett films, polymer brushes, etc. Hydrogels represent a broad research area with already existing practical applications; their biggest advantages include possibilities of incorporation of various particles, molecules, entities into the volume occupied by hydrogels. LbL assembly, where positively and negatively charged polyelectrolytes are sequentially applied, is often regarded as the substitute for Langmuir-Blodgett films, which are produced by drawing the substrate at a steady speed from a solution containing polymers. Flexibility of design of the coatings using LbL is one of their biggest advantages. Polymer brushes is another approach that 
allows to tailor functionalize the coatings, where their responsiveness to external stimuli is one of their biggest advantages.

Polymers stand out as a special class of materials due to the flexibility of design of their blocks and various functionalities, which is brought by their versatile assembly or by introducing additional side-groups or blocks, in the case of block-co-polymers. In this regard, both synthetic and biocompatible polymers are available, and polymer engineering represents a growing area tailoring the needs often driven by applications. With all advantages and the flexibility of the design, there is one significant weakness of polymers-the softness. In regard with tissue engineering, that translates to the fact that some materials can match predominantly soft tissue, but it is difficult to tune mechanical properties of polymers to match the hardness of bones, tendons, etc. And since mechanical properties of materials affect and even drive cell and tissue growth, enhancement of mechanical properties of polymers and biomaterials is essential. Chemical crosslinking can be applied to address these challenges, but that solves problems only partially.

To solve these challenges the so-called hybrid materials [6] are used, which possess both inorganic and organic contents. Increasingly, hybrid materials are used in designing the extracellular matrix. The hybrid matrix design for various tissue engineering applications should meet bio-medical requirements. On the one hand, it needs to be biocompatible and biodegradable, which is achieved through the polymeric or organic content, while on the other hand, stability and possess mechanical properties are needed to match those of a desired tissue-this is achieved through tuning the type, concentration, and distribution of the inorganic content. Each organ has different types of tissues that require different functionalization of polymer matrices [7]. For example, in the case of a tendon, one needs to create a hybrid material that should have excellent mechanical properties and allow integration of both bone and muscle tissue [6]. For such an organ as the lungs, there are different softness areas within the range to be matched by polymers, so tuning mechanical properties of materials is less essential. But in the case of the trachea, the mechanical properties play a very important role, and for the alveoli-the transport of substances and the rate of implant angiogenesis [8].

For hard tissue repair hybrid biomaterials are increasingly used [9]. In general, polymer-based hybrid biomaterials: (1) have extensive processing flexibility, tunable mechanical properties, and biodegradability; and (2) possess individual properties and controlled functions, which can be intelligently tailored to actively fill-in the needs of the regeneration in tissue engineering $[10,11]$. Another development in the area of polymer-based biomaterials for regeneration of hard and soft tissue are smart biomaterials [12]. Such smart functionality can be invoked by chemical, physical and biological stimuli [13-15]. Various stimuli allow controlling appropriate biodegradation profiles: as it was shown, for example, for polymers suspended in a solution [16], chemical triggering for bringing polymers together [17] or laser remote release of materials immobilized on bio-coating [18-20] through a localized temperature rise [21-23].

The addition of particles with encapsulated biomolecules allowed the implementation of the concept of both hardness modification and drug delivery with the coatings [24,25]. Such modification of the coatings can be well suited for applications in pharmacology [26], where delivery of molecules is just as essential as control over physico-chemical properties of films $[27,28]$ It is interesting to note that functionalization of hybrid assemblies [29] can be made with micro- or nano- particles, where the former size is more suited for thicker polymeric films and hydrogels [30,31], while smaller nanoparticles are better suited for tuning mechanical properties of less gelly films [32]. It is envisioned that the distribution [33] of such particles will allow to fully control the softness-hardness of films and other physico-chemical properties.

In addition to inorganic particles, various capsules provide the means of yet another type of modification of polymer-based films to promote the interaction with cells. There, drug or biomolecule delivery can be implemented in addition to mechanical properties control. Incorporation of capsules was applied earlier [34] using hyaluronic acid/poly-L-lysine exponentially grown films [35]. Such a versatile example allowed not only incorporation of capsules into films, but also remote activation of 
capsules by laser irradiation [36] and thus release from the coatings [37]. Polyelectrolyte multilayer capsules possessing growth factor and incorporated into polymeric films were shown to promote stem cell growth to bone cells [38]. Furthermore, various types of polyelectrolyte multilayer films can be functionalized with capsules and particles often in the form of calcium carbonate, as shown by $\mathrm{Li}$ and co-workers [39]. Microencapsulation has been shown not only to bring additional functionalities, but also to be used for controlling the rate of release [16]. Furthermore, addition of microcapsules allows brining-in sensor functionalities [40,41]. Mechanical properties of microcapsules can be tuned by studying deformation of capsules [42] together with release followed by fluorescence microscopy [43] so that the shape microcapsules can be changed [44] corresponding to the induced mechanical deformations.

Here, we discuss state of art and recent developments in application of innovative polymer-based and hybrid bio-materials addressing the needs of different tissue engineering areas. On the one hand, an overview of pure polymer-based as well as hybrid materials is made together with the methods of their assembly. While on the other hand, applications of these materials for interstitial and connective (tendon and the skin), vascular, nervous, visceral (lungs, kidney, liver), and musculoskeletal (cardiac, skeletal, cartilage and bones) tissues are discussed. A particular attention is paid to mechanical properties of coatings, since they most often enable application of these materials for different areas of tissue engineering. A summary of main properties of above mentioned materials is presented together with their applications in respective tissue engineering areas.

\section{Polymers in Tissue Engineering}

Nowadays, tissue engineering is one of the most interdisciplinary scientific research areas. Indeed, chemistry, materials science, engineering, physics as well as biology and medicine are combined in this area. Some key directions in tissue engineering is development of suitable bio-interfaces, their integration in appropriate tissues and control over their properties, for example, for release of active bio-molecules. This is achieved through an appropriate combination of a matrix (e.g., polymers) and bioactive molecules (e.g., growth factors or enzymes) and cells applied to specific tissues and organs.

The polymer matrix is one of the most important components of hybrid biomaterial. The matrix may consist of synthetic (polyglycolic acid (PGA), polylactic acid (PLA), polycaprolactone (PCL), poly (N-isopropylacrylamide) (PNIPAM)) [24,45-47] or natural (chitosan, alginate, collagen, hyaluronic acid, gellan gum, gelatin) polymers [48-51].

Suitable polymer scaffolds for tissue engineering should be biodegradable, biocompatible, and they should not cause mutations and a strong immune response [52]. In addition, scaffolds need to mechanically correspond to cells and tissues (to accompany differentiation of stem cells into the required cell type and stimulate proliferation) [53]. Another essential functionality of scaffolds is biodegradation, which can take place by means of enzymes. In the case of natural polymers, they are metabolized and removed from the body after some time [54].

\subsection{Syntetic Polymers}

Polyglycolic Acid (PGA) is one of the simplest linear, aliphatic polymers. Biodegradability and biocompatibility make this polymer convenient for creating biomaterials. PGA can be made by opening the glycolic acid ring [55]. PGA has been used more than once to create fiber matrices for tissue engineering [56]. PGA shows a very fast vascularization result within a week after implantation [57]. Hybrid materials are also successfully created on the basis of this polymer, for example PGA/hyaluronic acid to restore cartilage, PGA/collagen to stimulate vascularization [58].

Polylactic acid (PLA) is also an aliphatic polymer, which is used to create biomaterials owing to its biocompatibility. PLA is made from lactide ring opening polymerization [59]. It is often used in the form of parts for fastening bone tissues (screws and pins) [60]. In regard with hybrid implants, it is worth noting that the chitosan/PLA nanofibers coated with hydroxyapatite were used to accelerate 
bone tissue regeneration [61]. Also, PLA in various proportions with thermoplastic polyurethane (TPU) has exhibited good results in tissue engineering applications [62].

One of the most common synthetic polymers is polycaprolactone (PCL). PCL is a biocompatible and biodegradable polyester. The synthesis of PCL is carried out using an open-ring polymerization [63]. The main type of matrix for this polymer is nano and microfiber scaffold, which is formed by the electrospinning method [64]. A huge amount of hybrid biomaterials is formed from PCL for various types of tissues and organs. The only problem with PCL is a relatively poor cell adhesion [65]. Therefore, there is a large number of functionalization of this material from collagen to calcium carbonate [66,67]. Hybrid PCL materials can be applied to almost all types of tissues and organs from tendons to lungs $[68,69]$.

PNIPAM is a thermo-responsive polymer, which undergoes a phase transition from hydrated to dehydrated state at $32{ }^{\circ} \mathrm{C}$. Applications in tissue engineering have been developed, where a physical stimulus, temperature, has been used for changing the properties of coatings containing this. Specifically, a controllable cell attachment/detachment has been performed by increasing temperature of a solution containing cells, while the state of films, their hydration state and their mechanical properties have been characterized by atomic force microscopy (AFM) [70].

A relatively large number of charged polyelectrolytes exist for LbL applications. Although one of the most studied pair in the area of LbL is polyallylamine hydrochloride (PAH) and poly-styrene sulfonate (PSS), other polyelectrolytes have been also extensively used. These include: polydimethydiallylammonium chloride (PDADMAC), polyvinyl alcohol (PVA), poly-acrylic acid (PAA), polyethylene imine (PEI). In addition to these synthetic polymers, some natural/biodegradable polymers have been used including dextran sulfate, polylactic acid (PLA), poly-arginine, poly-L-lysine, hyaluronic acid (HA). Other natural polymers are discussed in the following section.

\subsection{Natural Polymers}

Alginate is a polysaccharide derived from brown algae. Due to specific structure, alginate is applicable in medicine. An alginate gel is formed by binding to two (or higher) valence ions [71]. An advantage of alginate is the capability to easily encapsulate animal cells [72]. But pure alginate has very poor adhesion properties, and only a modified alginate gel can adsorb cells on itself [71]. Composites of alginate with hydroxyapatite and bioglass are often used for bone tissue engineering [73]. Alginate is also often used to treat skin, including burn treatment $[74,75]$.

Collagen is the main component of connective tissue and the most abundant protein in mammals. Collagen makes up $25 \%$ to $45 \%$ of the proteins in the whole body. The collagen molecule is a left-handed helix of three $\alpha$-chains. This formation is known as tropocollagen [76]. Since collagen is a product of an animal body, it is metabolized quickly without causing an inflammatory reaction [66]. Typically, collagen is used to create hybrid biomaterials to improve cells adhesion [77].

Chitosan is a derivative of chitin, which originates from the shell of shrimps, molluscs, fungi. Boiling chitin in potassium hydroxide results in chitosan. Chitin is also biodegradable and does not cause a strong response from the immune system [78]. It has huge applications from medicine and biomaterials [61]. There are some limitations when working with chitosan, since the dissolution of chitosan occurs only with increased acidity, which makes some restrictions when working with cells and $\mathrm{pH}$-dependent molecules [79].

Hyaluronic acid (HA) is a naturally occurring, anionic glycosaminoglycan widely used in up-keep products to preserve moisture and smoothness of skin. It is also found in extracellular matrix (ECM) making it often sought for material in tissue engineering [80,81]. Coatings with HA are rather soft, which prompted application of cross-linking to it [82]. For example, HA is one of the most important constituents of the so-called exponentially grown LbL films [83].

Cellulose belongs to the family of linear chain polysaccharides. Peculiarly, cellulose has been also studied for applications in tissue engineering [84]. Biodegradability of cellulose can be an issue 
for application in tissue engineering, because it either does not degrade or degrades very slow (over 60 weeks) [85].

\subsection{Assembly of Polymers into Coatings and Films: Hydrogels, LbL, Langmuir-Blodgett Films, Polymer Brushes, 3D Printing}

Hydrogels are very useful but, at the same time, some of the softest bio-materials [86,87]. Functionalization of hydrogels with inorganic particles leads to enhancement of their mechanical properties through, for example, additional bio-mineralization [50] and incorporation of possibilities to release encapsulated materials or antibacterial properties [88].

Discussed by Decher, LbL films have seen two decades of rapid development [89-94], where both versatile planar layers and fully suspended polymeric capsules have been established. Typically, LbL films are quite thin, but a special design of the so-called exponentially grown films leads to micrometer thick gel-like films [95], which are applicable for tissue engineering. In this regard, the deposition time affects the uptake of polymers [96] and water [97]. The flexibility of the design of LbL coatings enables extensive opportunities including those in tissue engineering, where vascular patches [98] have been designed. Detachable cell sheets for tissue engineering have been reported [99].

Another desirable feature for tissue engineering is patterning, which was also reported for LbL structures [100]. Differentiation of stem cells has been obtained with LbL coatings [101]. Adhesion of cells can be promoted either by patterning [102], chemically patterning the LbL sources [103] or by adjusting mechanical properties [104]. Adjusting the mechanical properties, which can be done by addition of gold nanoparticles on the surface, allows not only for controlling cell adhesion, but also to controllably embed and pattern particle $[105,106]$.

Composite LbL films containing inorganic nanoparticles allow one to control cells adhesion, while also giving the material the required properties (stiffness, antibacterial properties, etc.) [107]. Polymer brushes represent polymers attached or tethered to a surface [108]. To distinguish between, for example planar LbL layers, the density of polymers constituting polymer brushes is said to the higher than the gyration radius of polymers. Application in tissue engineering can be also thought with polymer brushes [109]. Control of rigidity, reversible physico-chemical properties and stimuli-responsiveness [109] are noted as some distinct properties of polymer brushes making them unique materials in tissue engineering.

In addition, 3D printing is a rapidly expanding area due to availability of new instruments and materials [110-112]. Several approaches to 3D printing are available including fused deposition modelling, selective laser sintering, stereolithography, near-field electrospinning, and bioprinting, where inkjet printing, laser-assisted 3D printing, extrusion [113,114].

\subsection{Pure Polymeric Coatings Targeting Different Tissues}

Numerous applications in tissue engineering are developed using the so-called hybrid materials, where polymers are supplemented by inorganic particles. But this is not always the case, and there are still applications where pure polymers are used for constructing scaffolds or other structures for tissue engineering.

One of the most important criteria for selecting pure polymers for various applications in different tissues and organs is their mechanical properties [115-117]. Indeed, human tissues have their own rigidity depending on the type of cells and their structural organization [118]. Peculiarly, mechanical properties of tissues range from $\mathrm{kPa}$ to GPa, based on data for arterial walls [119], brain [120], breast [121], bone [121], cartilage [122], cornea [123], heart [124], kidney [125], liver [125], prostate [126], vein [127], skin [127] and tendon [128]). A summary of these data is given in Figure 1. Analyzing these data, it can be seen that chest and liver have a very low modulus of elasticity of about $1 \mathrm{kPa}$, which is similar to that of polyacrylamide. Bones, on the other hand, have relatively speaking extremely high rigidity (of the order of $10 \mathrm{GPa}$ ), which can be matched by poly (methylactrylate) with rigidity in the range of 2 to $4 \mathrm{GPa}[129]$. 
Furthermore, such natural polymers as collagen, gelatin, alginate and agarose gels have good biocompatibility, but they are only suitable for soft tissues [130]. Synthetic polymers have a fairly wide range of stiffnesses, but they can cause inflammation in the body, and often have problems with cell adhesion [131].

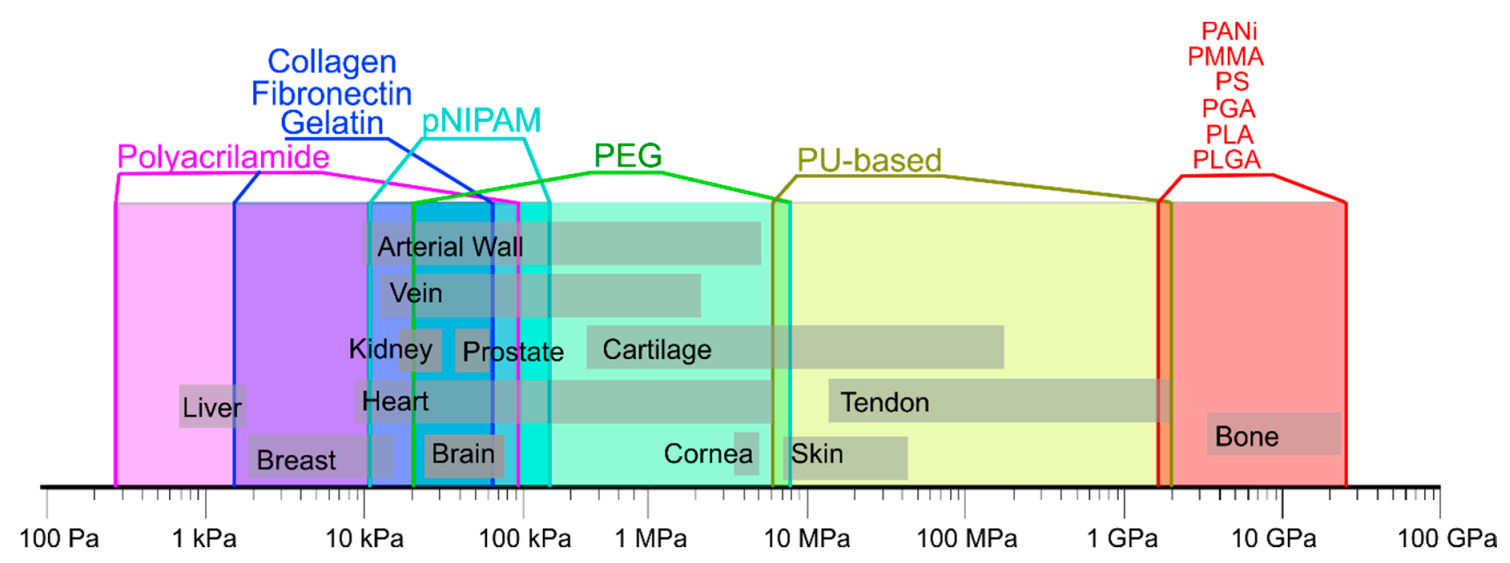

Figure 1. Mechanical properties of natural tissues and polymers. Data are composed based on data from the following publications $[25,131,132]$.

It is these aspects that limit the use of pure polymers for tissue engineering prompting to use of hybrid materials, which are overall better suited for fine-tuning of relevant properties of implants [131], and can be also used for drug delivery through incorporated particles. In the following section, hybrid materials are discussed in regard with their applications in specific tissue engineering areas [25].

\section{Hybrid Biomaterials for Interstitial and Connective Tissues Reconstruction}

\subsection{Hybrid Biomaterials Applied for Tendon}

The transfer of power between the musculoskeletal tissues is due to tendons and ligaments. The structure of the collagen fibrils that make up the tendons ensures their strength and elasticity. The main components of tendons are fibrillar, fibril-associated (I, III, IV, V), beaded filament-forming (VI), and network-forming collagen (IV), a large amount of elastin and decorin proteins are also present, expression of chondroitin and proteoglycans by cells provides for swelling in the aquatic environment. The orientation of cells inside the tendons occurs around collagen fibers-this positively affects also the mechanical properties $[128,133]$. The insertion of the tendon in the bone consists of three continuous regions, in which the soft tissue transforms in fibrocartilage and, then, in a bone. The fibro-cartilaginous region is further divided into calcified and noncalcified regions. These complex transitions are essential for the biological fixation of the tendon and exhibit a gradient of structural and mechanical properties ( $>310 \mathrm{kPa}$ ) to transmit complex loads between the tendon and the bone insertion site [134]. To mimic these structures, hybrid materials with engineered matrix inhomogeneities and structures are required. A wide variety of such synthetic and natural polymers as PCL, PGA, polyurethane, collagen, and silk fibroin, and a variety of scaffold production methods have been used to develop functional matrices for tendon and ligament tissue $[66,135,136]$. The base for tendon implants is made using polymers matrix, which can be obtained by electrospinning due to their architecture and good mechanical properties, but in connection with poor cell adhesion of the pure polymers and tendon construction often use collagen coating. Also, fibro-cartilaginous region formation stimulated by calcium-based nano and microparticles of hydroxyapatite $[68,137]$. A striking example of a solution to this problem is the work of Savelyeva et al. They coated PCL nanofibers by $\mathrm{CaCO}_{3}$ particles loaded tannic acid. It was reported that particles improve cell adhesion on the surface of the PCL implant, and when connected to the bone, after a while passed into the form of hydroxyapatite, which significantly improved the integration of the implant on both sides [138] (Figure 2). 


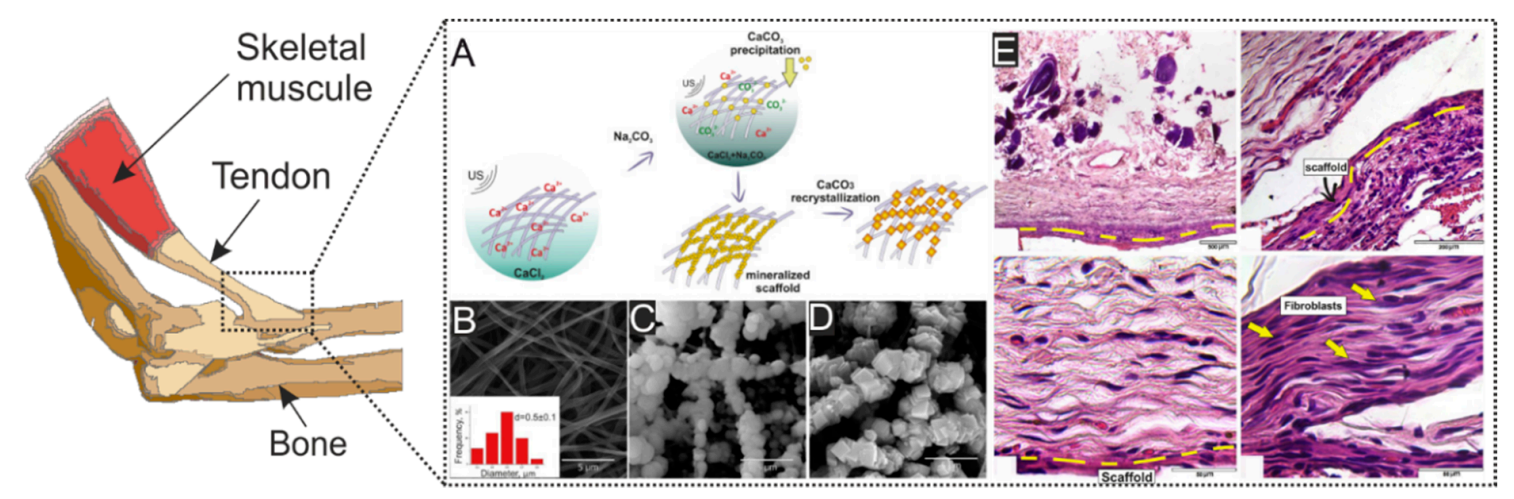

Figure 2. (A) Scheme of ultrasonic mineralization of polycaprolactone fibers and recrystallization of vaterite to calcite. (B) Microphotographs show pristine PCL fibers. (C) the mineralized scaffold based on PCL material. (D) process of recrystallization vaterite to calcite. (E) Micrograph of histological sections, 21 days after implantation in the withers of the mouse. Yellow dashed lines indicate the location of the matrix. Reprinted with permission from Elsevier, 2018 [138].

\subsection{Hybrid Biomaterials Applied for Skin}

Knowledge of native tissue is one of the major factors in successful development of biomaterials for regenerative medicine [139]. Skin is the biggest organ of the human body, which has a lot of functions, some of them are protection, sensation, thermoregulation, control of evaporation etc. Skin includes two anatomically, functionally, and developmentally distinct tissues: the epidermis, which has a role of barrier to infection and regulator of transdermal water loss, and the dermis, which has mechano and thermoreceptors, hair follicles, different glands and vessels [140]. When developing biomaterials for skin regeneration, it is important to remember that the main components of a successful biomaterial are ECM, cells and bioactive molecules that help cell growth or differentiation [141,142].

In the case of the development of skin implants, scientists can start using not only pure polymers, because the restoration of the skin occurs much faster if one uses various combinations of polymers with nano- [143] or micro- [67] particles and bioactive substances [144]. Hydrogels can be also used, because, although they are soft, skin represents also a soft tissue [145-148]. It should be added that the Young's modulus of skin is in the range from 4.5 till $8 \mathrm{kPa}$ [134], that is why materials should match these values. Mechanically affected regions of skin are usually located near to the surface that may lead to a rejection of implants due to contamination and inflammation [149]. One solution to this potential problem is a modification of polymer hydrogels and fibers by microcontainers or microcapsules with, for example, tannic acid, which has antimicrobial properties. This would resist fibrosis and would improve angiogenesis of tissues $[138,148,150,151]$. It should be noted that signals generated by VEGF and TGF play an important role for proper regeneration of skin tissue and healing of wounds [144,147,152,153].

\section{Hybrid Biomaterials for Vascular Tissue Reconstruction}

Tissue engineering of vascular tissues is one of the major application areas of tissue engineering, because cardiovascular disease is linked to one of the highest number of death cases. Treatment for cardiovascular diseases can include a complete replacement of a destroyed vessel with an artificial one. Delivery of oxygen-rich blood from the heart to the different tissues is particularly important for blood vessels [154].

Arteries represent a muscular tube lined by smooth tissue. It has three layers: the intima, which presents a single layer of flat cells, the media, which present the thickest layer in arteries and rich in vascular smooth muscle, and the adventitia, which represent the thickest layer in veins and entirely made of connective tissue [155]. Such a vessel architecture allows you to experience high pressure from the heart (from 1600 till $8250 \mathrm{mmHg}$ ) [156]. 
One of the useful polymers for vessels engineering of medium-large diameter blood vessels is expanded polytetrafluoroethylene (ePTFE), because of its high crystallinity and hydrophobicity. These two characteristics of ePTFE ensure the prevention of hydrolysis. But for small diameter vessels using ePTFE can be dangerous because of intimal hyperplasia, calcification, and thrombosis [157]. Therefore, a biodegradable implant is considered the best option, which will be replaced by vascular cells, preserving the architecture of the vessel, but without losing its mechanical properties [158].

In most cases, coatings of implants for vessels should contain bioactive molecules, which speed up vessel's integration. One of them is vascular endothelial growth factor (VEGF)-a family of signal proteins produced by cells for stimulating the formation of blood vessels. Interesting work in vessels implant area is done by the Gonzalez-garcía group. In that work, poly (ethyl acrylate) was shown to lead to the formation of fibronectin networks, where VEGF-presenting areas were generated, (Figure 3), which promote vascular cell response. Such a system allows to use extremely low doses of the growth factors, while at the same time improves vascularization. As such, it is robust and efficient approach to improve vascularization of the tissue and in can be implemented in 2D and 3D scaffolds [159].

A

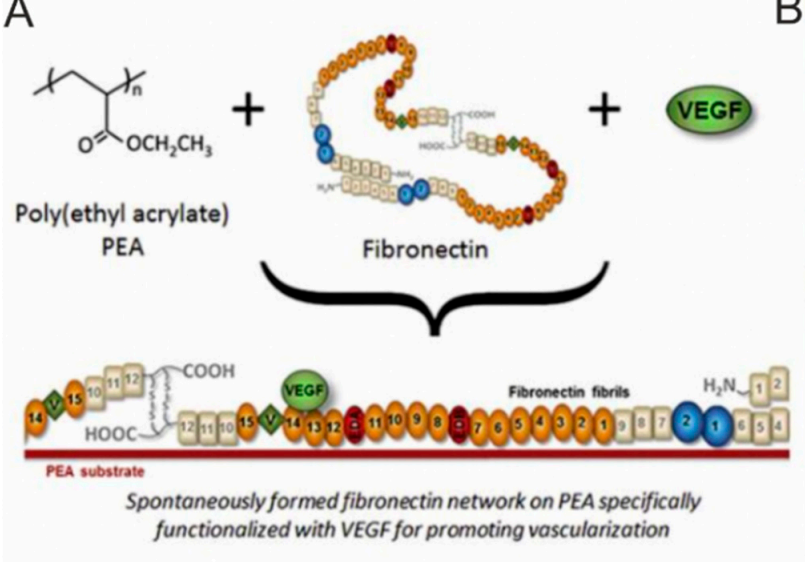

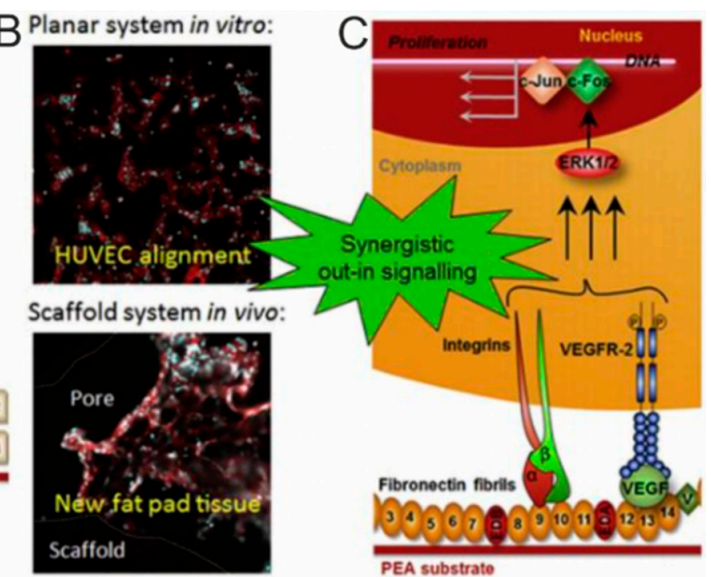

Figure 3. (A) Synergistic triggering of the integrin-VEGF signal, which is connected to the Poly (ethylene adipate) network. (B) In vitro and in vivo fluorescence microphotographs of cells. (C) Scheme of the effect of VEGF associated with nanofibrils on cell signaling. Reprinted with permission from Elsevier, 2017 [159].

\section{Hybrid Biomaterials for Nervous Tissues Reconstruction}

The causes of death of neurons, astrocytes, and oligodendrocytes may be apoptotic or necrotic. The causes of death and poor functionalization can also be axon damage, demyelination, ischemia, oxidative damage, and inflammation. The main problem of neural tissue regeneration is the complete lack of stimulating growth and migration factors, but there are factors responsible for inhibiting axon growth. In this regard, the damaged area quickly forms a healed scar, which is a chemical and physical barrier to regeneration [160]. Therapy of damaged areas is very difficult due to the architecture of the central nervous system. Cell transplantation is also difficult to achieve due to adverse conditions at the lesion sites. These factors make neural tissue engineering one of the most complex. Nowadays, the area of nanofibers consisting of natural and synthetic polymers receives substantial scientific interest.

One of the main approaches of tissue engineering of nerves is the creation of nerve conduits and the replacement of damaged ones. New conduits can be synthetic, biological or hybrid, which are biosynthetic. Synthetic polymers such as polyester, polyurethane, and polyols are widely used to create conduits. Also, biological polymers can be used to create them: polyesters, proteins, and polysaccharides [161]. Nerve conduits can be of three types: tubular, fibrous and matrix. A striking example is the creation of a hybrid fibrous nerve conduit, which consists of PCL and gelatin. Fibrous PCL has an excellent architecture for cell migration, and gelatin stabilizes the electrically pumped PCL 
fibers and provides good cell adhesion. The growth of neurons in the hybrid conduit showed a better differentiation and migration of neurons than that for a channel consisting of only one component [162].

Also, for good survival and treatment of damaged nerve sections, growth factors such as nerve growth factor (NGF) [163], neurotrophin-3 (NT-3) [164,165] and brain-derived neurotrophic factor (BDNF) [166] should be included in biomaterials.

Hydrogel implants consisting of agarose, hyaluronic and polyethylene glycol and containing a ciliary neurotrophic factor (CNTF), sonic hedgehog (SHH) [167], vascular endothelial growth factor-165 (VEGF165) [168], and EGF [169], as well as cell-adhesive arginylglycylaspartic acid (RGD peptides) [169] have been created. Martino et al. showed the incorporation of VEGF, PDGF, and bone morphogenetic protein-2 growth factor into the same binding site as integrin on fibrin fibers. This approach increased the biological activity of the growth factor [170].

Mechanical properties are some of the most important characteristics for nerve regeneration. A good flexibility of the implant helps to avoid axon destruction at the bending of the nerve [171,172]. An implant that is too rigid can compress the growing tissue [173]. But a substantially weak mechanical strength of the matrix can lead to breakage, rupture, and kinks of the nerve. Thus, an optimal polymer or copolymer ratio must be ascertained through experimental studies [172]. Using hydrogels as one of the components for creating hybrid implants, it is worth emphasizing the importance of swelling. As a result of swelling, axons are compressed, and their growth is disturbed. Swelling occurs due to the accumulation of conduit decomposition products, and it is controlled by changing the ratio of the polymers [174]. Optimal degradation should be uniform along the entire length of the implant, because, too fast degradation causes inflammation and swelling, and too slow degradation causes compression [172].

\section{Hybrid Biomaterials for Visceral Tissue Reconstruction}

\subsection{Hybrid Biomaterials Applied for Lungs}

To create hybrid materials for tissue engineering of the lungs, one must have a good understanding of the anatomy and physiology of this organ [175]. Anatomically, the lungs are divided into two sections-the proximal and distal airways. The proximal respiratory ( $>2 \mathrm{~mm}$ internal diameter) consists of the pseudostratified epithelium. The pseudostratified epithelium is multilayered: the basal layer (discontinuous layer of the basal cells) and the luminal layer (ciliated cells, Clara-like cells (secretory club cells), human goblet cells, and neuroendocrine cells that aggregate to form neuroendocrine bodies). The distal airway (small bronchi and bronchioles) consists of a single layered epithelium containing Clara cells, ciliated cells, neuroendocrine cells, and p631Krt51 basal cells [176].

Alveoli are located in the most distal part of the lung and consist of two types of epithelial cells: alveolar type I cells (AEC I) and cuboidal alveolar type II cells (AEC II). Alveolar type I cell provide a gas exchange surface. Cuboidal alveolar cells containing secretory vesicles filled with surfactant [176]. Park et al. have hypothesized that a biodegradable implant that "disappears" over time will have a good effect on the regeneration of tracheal tissue and facilitate the approximation of native tissue (Figure 4A) [8]. The authors used a hybrid implant consisting of L-lactide and $\varepsilon$-caprolactone, which was synthesized by ring-opening polymerization (P [LA/CL]). Such a hybrid matrix decomposes in 2-3 months in vivo by hydrolysis. A special advantage is the high porosity of such a matrix- $-80 \%$. Pores have a size of approximately 20 to $100 \mu \mathrm{m}$, which allows cells to migrate into the implant. It was also possible to strengthen the matrix due to the gelatin coating, which also improved cell adhesion on the surface $[69,177]$. This is not the only example of the successful use of hybrid matrices. Also, the gelatin matrix coated with PLCL/TGF-B1 with cultured chondrocytes on the surface showed good results in vivo experiments (Figure $4 \mathrm{~B}$ ). Within 8 weeks after implantation, the matrix retained its mechanical properties, despite the gradual replacement by native tracheal tissues (Figure 4B) [8]. 

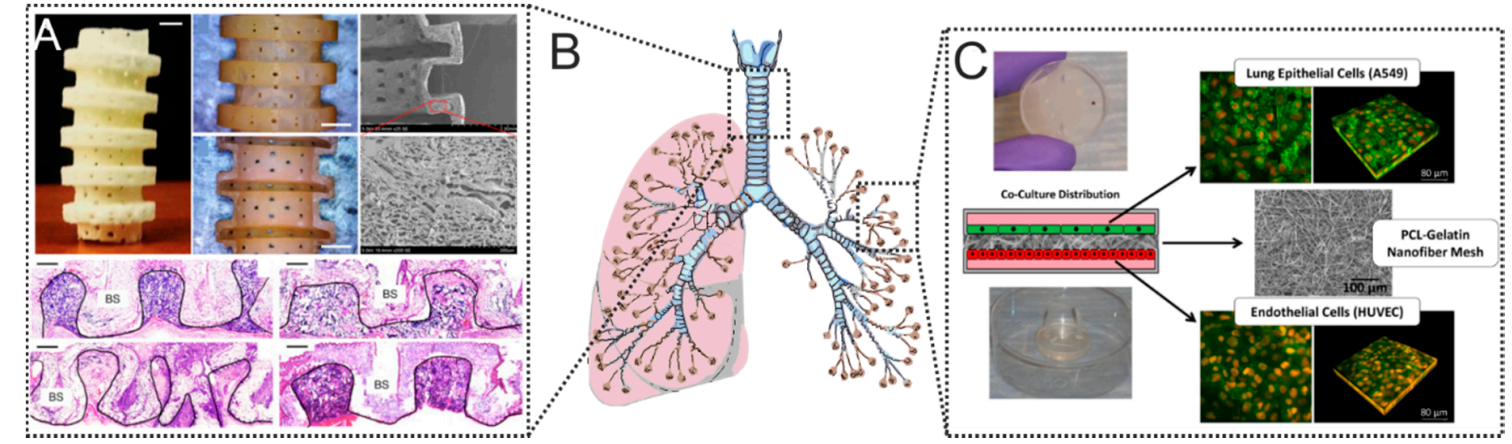

Figure 4. (A) Image of a tracheal implant (appearance and section). SEM micrograph of the outer wall and slice. Scalebar $2 \mathrm{~mm}$. Histological Section 8 weeks after implantation. Reprinted with permission from Elsevier, 2015 [8]. (B) Schematics showing lungs, where 3D printed scaffolds shown in (A) can be incorporated, and which can be modeled by microfluidic devices depicted in (C). (C) Schematics of the co-culture system and images of assembled fluidic devices with cells including confocal laser scanning images of epithelial and endothelial cells co-cultured on a 75/25 (PCL/gelatin) fiber mesh. Reprinted from [173] with permission from Nature Publishing Group, (c) 2017.

Higuita-Castro et al. have been successful in developing a platform that mimics the micro/nanoscale architecture of the alveolar environment. They used this system to study the effect of the structural properties of the ECM on damaged epithelial cells during the reopening of the airway (Figure 3C). Gelatin coated PCL nanofibres are used to adjust Young's modulus. As a result, it was found that the stiffness of hybrid matrices significantly affects the barrier function of the epithelium/endothelium. An increase in the rigidity or density of the matrix led to a change in the structure of the cytoskeleton and a change in cell permeability [178].

\subsection{Hybrid Biomaterials Applied for Kidneys}

Kidneys perform the following essential functions: excretion and filtration of metabolites, regulation of the electrolytes, fluids, the balance of acids and bases, and maintenance of the production of red blood cells (RBC). The renin-angiotensin-aldosterone system of the kidneys is also responsible for regulating blood pressure [179].

An important factor in tissue regeneration in the kidneys is the cellular microenvironment, which can be adjusted by the proper engineering of hybrid materials. One example of success using hybrid material is hyaluronic acid/collagen crosslinked with PEGDA and loaded stromal cell-derived factor-1 (SDF-1). This hybrid material was also used as an endothelial progenitor for cell delivery system. There, hydrogel protects EPCs from cytotoxic insult. SDF-1 loaded into hydrogel stimulated proliferation and increased cell engraftment in kidneys $[180,181]$. It should be noted that such strategies for using hybrid polymer hydrogels as cell carriers for kidney reparation are used quite often [182-185].

Lih et al. developed a PLGA matrix coated with $\mathrm{Mg}(\mathrm{OH})_{2}$ and acellular ECM. $\mathrm{Mg}(\mathrm{OH})_{2}$ can affect the acidity of the cellular microenvironment, which changes during the decomposition of the PLGA. As a result of reducing the acidity of the microenvironment, the inflammatory effect is also reduced. The ECM also improves the normal biological function of cells on the matrix [186].

Growth factors are a promising component of polymer-based hybrid materials. Hybrid materials can also be used for kidney tissue, as it is closely related to kidney regeneration in renal failure [186]. The acellular ECM could promote the normal biological function of kidney cells.

Classical methods for coating polymers with growth factors are adsorption and chemical bonding $[159,187]$. The healing process needs the replacement of damaged tubular cells to restore the connection of the renal epithelium. This process includes some growth factors that are provided in renal tissues. The growth factors include epidermal growth factor (EGF), a potent proximal tubule cell mitogen [188]; transforming growth factor- $\alpha$ (TGF- $\alpha$ ), a participant in the reconstruction of the injured 
proximal tubule via the EGF receptor [188]; insulin-like growth factor 1 (IGF-1); fibroblast growth factor (FGF), and hepatocyte growth factor (HGF) [189].

\subsection{Hybrid Biomaterials Applied for Liver}

The largest internal organ in a body is the liver, which performs hundreds of different functions that help the normal body homeostasis [190]. Damage to tissues or cells that entail hepatic pathology provokes a change in physiology and metabolic activity. Although the liver has a high regenerative ability and can completely restore its mass and function, some disorders affect the physiology so much that therapy is required to restore its functions. Typically, these effects cause hepatitis, cancer and various toxins, such as drugs and alcohol [191].

Hybrid polymeric materials are actively used for tissue engineering of the liver too. Due to them, there is the possibility of current adjustment of cell adhesion and migration. Earlier, natural (cellulose, chitosan, gelatin, alginate, collagen, fibrin, heparin, hyaluronic acid) and synthetic (PVA, PLA, poly(N-isopropylacrylamide), poly (lactide-co-glycolic acid) and PCL) polymers have been applied for tissue engineering of the liver. Besides, growth factors and specific enzymes have been be used as one of the components of the hybrid matrix [192-194].

Currently, hybrid polymeric materials are already actively used in tissue engineering of the liver [195]. The adhesion peptides RGD or YIGSR significantly improved the adhesion of hepatocytes on the surface of PCL and PLA, compared with pure polymers [196]. Lee et al. showed a polymer poly (ethylene glycol) diacrylate (PEGDA)/hyaluronic acid-coated with a synthetic peptide Gly-Arg-Gly-Asp-Ser (GRGDS). This semi-permeable gel supported the differentiation of hepatocytes for 16 days [197]. The 3D sandwich culture of hepatocytes between the top and bottom layers maintained their functional state over a period of 14 days. Such cultures were even faster than collagen sandwich cultures in the rate of tissue formation [198]. Qui et al. modified PCL scaffold with galactosylated chitosan and showed an improved hepatic functionality over a period of 7 days as compared to a 2D monolayer or PCL 3D scaffold [199].

\section{Hybrid Biomaterials for Musculoskeletal Tissue Reconstruction}

The replacement of bones, cartilage and skeletal muscle are the most essential goals of musculoskeletal tissue engineering. Although the cell type and even their source as well as materials themselves influence the tissue growth, new developments, recent progress in this area allows for effective cell cultivation and growth. The following polymers with their particular advantages have been used in musculoskeletal tissue engineering: collagen (cell differentiation), Matrigel (proliferation), Sylgard (matrix formation), fibrin gels (cell survival), PGA (vascularization), alginate (adhesion), PCL (adhesion), hyaluronic acid (immunogenicity) [200]. Just like in other application areas, patterning of gels [201,202] is essential as well as application of natural and synthetic polymers [203] is essential for musculoskeletal tissue engineering. Overall, the designed scaffolds should withstand forces of external environment and match or mimic the properties of cells surrounding them.

\subsection{Hybrid Biomaterials Applied for Cardiac Muscle}

One of the leading causes of death in developed countries is cardiovascular disease. The regenerative capabilities of the heart muscle are extremely limited; as a result, millions of cardiomyocytes die after myocardial infarction [204,205]. After a myocardial infarction, a scar forms within 4-6 weeks. This collagen scar, consisting of fibroblasts and endothelial cells, significantly reduces the contractile function of the heart. Such a change leads to heart failure. An appropriate combination of polymers, bioactive molecules and cells can help restore cardiac muscle function after such injuries [206].

A striking example of an application of a hybrid material is the use of an elastomeric framework of nanofibers treated with macromer-thick layers of acrylate poly (glycerolebacinate) (Acr-PGS) obtained by electrospinning. Gelatin was used as the polymer, which stimulated the adhesiveness of cells onto the scaffolds. The obtained scaffolds have different mechanical properties, depending on the ratio of 
the polymers used (tensile modulus from $60 \mathrm{kPa}$ to $1 \mathrm{MPa}$ ) and degradation rate (weight loss from about 40 to $70 \%$ by the beginning of the 4 th month). At different polymer ratios, a difference was also observed in the chemical response of the recipient to implantation [207]. A heart patch was constructed from poly (glycerol subacute) and was found to be sufficiently active even without gelatin for cell adhesion for more than three months [208].

\subsection{Hybrid Biomaterials Applied for Skeletal Muscles}

Skeletal muscles recover well in response to minor injuries, but serious damage can cause fatal consequences in muscle activity if therapy is not done on time. Hybrid biomaterials that provide chemical and physical signals can help improve muscle regeneration. The two main factors for restoring muscle work are the angionization and innervation of the implanted scaffold. An important factor in the survival of an implant after transplantation into muscle tissue is its vascularization. Often, to accelerate this process, implant pre-vascularization is carried out, for example, a matrix consisting of fibrin/poly (lactic-co-glycolic acid) is pre-seeded with a mix of fibroblasts and myoblasts. The matrix with cells is transplanted to the recipient. After a couple of weeks, angiogenesis and anastomosis of the vascular system of the recipient with implant begin. After that, this matrix is transferred to the damaged area, preserving the vasculature [209]. Also, polymers are coated with arginine and laminin before implantation, which improves the clustering of acetylcholine receptors [210,211]. This procedure improves subsequent tissue innervation [211]. When cultured with neurons, such myofibrils form acetylcholine receptors at the border of two cell types. When exposed to glutamic acid, one could observe shortening [212,213].

\subsection{Hybrid Biomaterials Applied for Cartilage}

Cartilage defects are some of the most common problems of orthopedics, while similar pathologies result from trauma, aging, etc. Cartilage has a very low ability to regenerate since it only consists of chondrocytes. Cartilage tissue lacks innervation and vascularization [214]. One of the most used form of polymers for the regeneration of cartilage tissue is a hydrogel. Hydrogel implantation procedures can be minimally invasive (injection or arthroscopy). The advantage of using polymer hydrogels is its properties: swelling and lubrication [215-217]. Mechanics can be also added to this list provided that the hardness can be tuned with an inorganic content in hybrid hydrogels. These properties are also inherent in native cartilage tissue, which allows the implanted material to successfully mimic the tissue. The morphology of the cells inside the hydrogel is mainly spherical, which is characteristic of chondrocytes [218]. One of the hybrid hydrogels used to regenerate cartilage is polyethylene glycol (PEG)-based hydrogel with methacrylate groups for photo-crosslinking [215]. When growth factors are added to such hydrogels, a significant acceleration of the cartilage formation of tissue by stem cells is observed [219].

\subsection{Hybrid Biomaterials Applied for Bones}

One type of tissue with an inherent regenerative capability is bone tissue [220]. However, if the disturbances or injuries are too extensive or the regeneration process has been interrupted by a new exposure, major healing problems may arise. There is also a big problem with bone regeneration for old people due to osteoporosis. In all these cases, an exterior intervention is required [221]. The bone mainly consists of connective tissue, which is continuously undergoing the destruction of old sites and the creation of new ones, by osteoclasts and osteoblasts, respectively. This occurs due to high physical stress on these tissues [222]. For material scientists, bone is a matrix composed of polymers (collagen) and ceramics (hydroxyapatite). Therefore, the use of hydrogel and ceramics can improve implant engraftment both at the cellular (good adhesion and fast differentiation) and at the organism level (mechanical properties required for bone tissue) [223].

An important parameter for creating hybrid materials for bone regeneration is the ability to promote primary biomineralization. For example, when using PCL fibrous matrices (fiber $\varnothing 50 \mu \mathrm{m}$ ) 
coated with calcium phosphate, biomineralization occurs much faster than that on pure PCL. Such polymer coatings increase alkaline phosphatase activity and accelerate in vivo bone formation [224]. It was also demonstrated that implantation of only ceramics did not lead to an acceleration of osteogenesis [225]. This indicates the need for a stable surface. That is why hybrid materials are so in demand for bone therapy $[226,227]$.

Grafting of enzymes can be also used for promoting the cell adhesion. In this regard, it was recently shown by Muderrisogly et al. that an enzyme (alkaline phosphatase, ALP) can be immobilized onto a titanium surface with a alginate hydrogel (Figure 5) [228]. This was carried out in several steps: (1) the mineralization of a titanium substrate by $\mathrm{CaCO}_{3}$ particles; (2) the adsorption of ALP enzymes; (3) the coating the substrate with the alginate hydrogel. Further, this structure is mineralized again, and ALP molecules are adsorbed on it. This design provides the implant with all the substances necessary for osteogenesis and improves the anti-corrosion properties of the matrix [229].

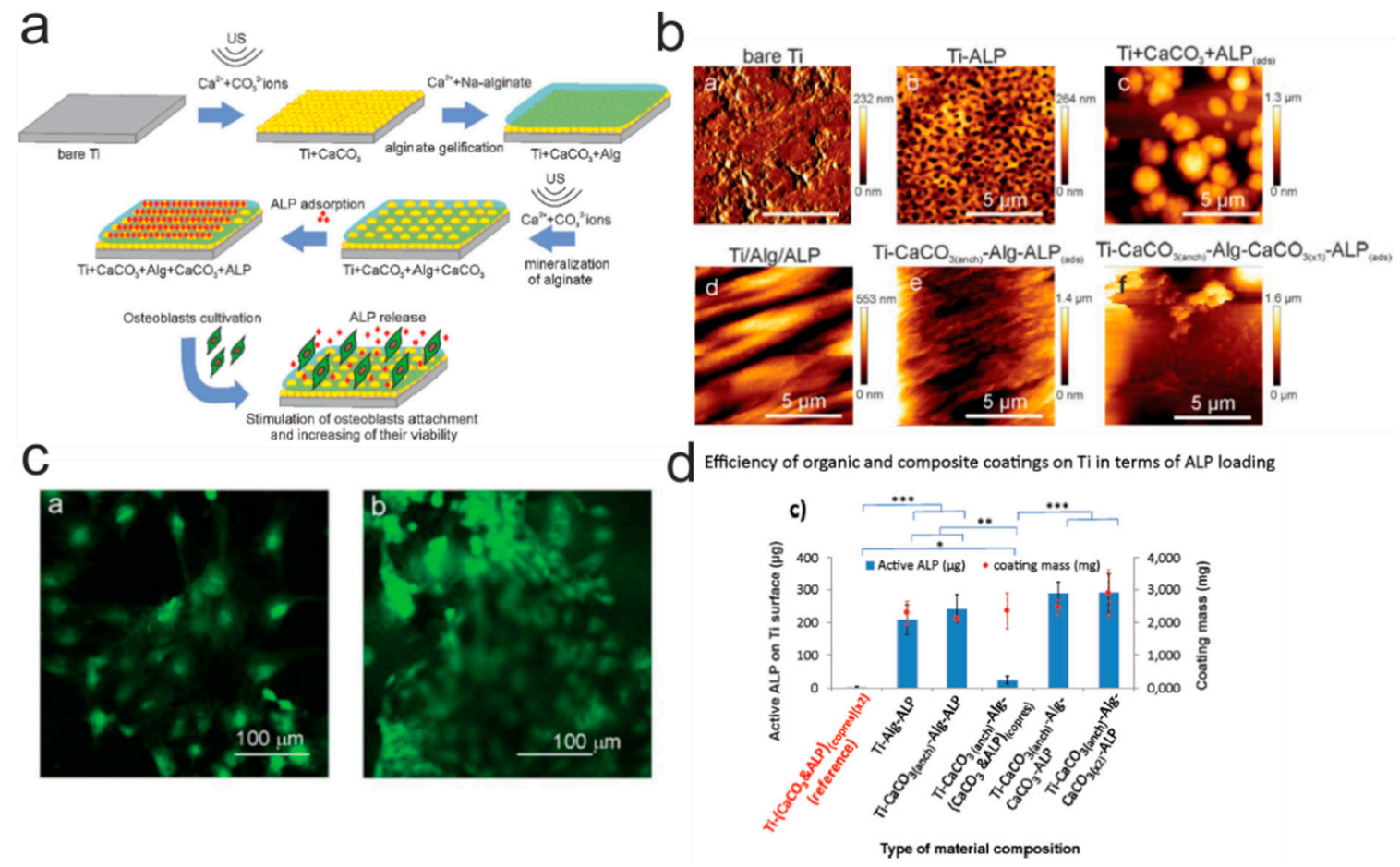

Figure 5. (a) Scheme depicting the creation of a composite material based on titanium and alginate gel. (b) Atomic force microscopy topography images of functionalized surfaces. (c) Fluorescence photographs showing osteoblast cells on the surface of a composite material. (d) Analysis of the amount of active enzyme by a different combination of components of the composite material. Reprinted with permission of Wiley, 2018 [228].

One can see from data discussed above that the invent of hybrid materials enable the so-called "all-in-one" concept. There, a polymer can be taken, modified by inorganic content, and tuned to match required properties of desired tissues or organs.

From discussion above, it is clear that pure polymer and hybrid materials have been used in various applications in general area of tissue engineering. These applications are often so distinct that they often are considered almost as stand-alone areas. Some selected applications are shown in Table 1 presenting tissue/organ type, coatings applied there, the type of polymers as well as targeted functionality. 
Table 1. Representative examples of polymer-and hybrid-based biomaterials with specific coating for interstitial, connective, vascular, nervous, visceral and musculoskeletal tissues.

\begin{tabular}{|c|c|c|c|c|c|}
\hline Tissue Type & Tissue or Organ & Coating for Specific Tissue Type & Polymer as the Base of Coating & Functional Element of the Coating & Refs. \\
\hline \multirow{14}{*}{$\begin{array}{l}\text { Interstitial and } \\
\text { connective } \\
\text { (Section 3) }\end{array}$} & \multirow{6}{*}{$\begin{array}{l}\text { Tendons } \\
\text { (Section 3.1) }\end{array}$} & $\begin{array}{l}\text { Collagen (hR COL and BAT COL), } \\
\text { gelatin }\end{array}$ & PCL & Improving cell adhesion & {$[66,135,230]$} \\
\hline & & $\mathrm{CaCO}_{3}$ microparticles/PCL & PCL & $\begin{array}{l}\text { Imitation of fibro-cartilaginous region and improving of } \\
\text { cells adhesion }\end{array}$ & [138] \\
\hline & & $\begin{array}{l}\text { Tricalcium phosphate } \\
\text { nanoparticles/PCL }\end{array}$ & PCL & Imitation of fibro-cartilaginous region & [68] \\
\hline & & Collagen based & Silk & Improving cell adhesion & [231-233] \\
\hline & & $\begin{array}{l}\text { Maleic anhydride/cellulose } \\
\text { nanocrystal based }\end{array}$ & PLA & Improving connection between two components and cells & [136] \\
\hline & & Hap based & PLLA & Imitation of fibro-cartilaginous region & [137] \\
\hline & \multirow{8}{*}{$\begin{array}{c}\text { Skin } \\
\text { (Section 3.2) }\end{array}$} & Gelatin based & Chitosan & $\begin{array}{l}\text { Macrophage activation, high hemostatic effect and no } \\
\text { antigenicity. }\end{array}$ & [145] \\
\hline & & $\begin{array}{l}\text { Collagen with immobilized } \\
\text { epidermal growth factor (EGF) }\end{array}$ & PCL and PCL/Gelatin & $\begin{array}{l}\text { Improving cells adhesion and stimulation of mitosis via } \\
\text { regulation of } \mathrm{Ca} \text { and } \mathrm{pH} \text { inside cells }\end{array}$ & {$[146,147]$} \\
\hline & & Micelles with tannic acid & PCL/Collagen mix & Improving of angiogenesis and antimicrobial properties & [148] \\
\hline & & $\mathrm{CaCO}_{3}$ with tannic acid/PCL & PCL & Improving of angiogenesis and antimicrobial properties & [67] \\
\hline & & Platelet lysate & PCL/PLCL & Haemostatic plug stops bleeding & [234] \\
\hline & & PLGA based & VEGF and TGF- $\beta 3$ & Differentiation and angiogenesis of cells. & [144] \\
\hline & & PCL based & EGF + VEGF & Differentiation and angiogenesis of cells. & [152] \\
\hline & & $\begin{array}{l}\text { Chitosan microparticles loaded with } \\
\text { growth factors }\end{array}$ & Dextran-based hydrogel & Differentiation and angiogenesis of cells. & [153] \\
\hline \multirow{5}{*}{$\begin{array}{l}\text { Vascular } \\
\text { (Section } 4)\end{array}$} & \multirow{5}{*}{$\begin{array}{l}\text { Blood vessels } \\
\text { (Section } 4)\end{array}$} & Fibrin glue with FGF-1 and heparin & ePTFE & Increasing capillarization, increased collagen content & [235] \\
\hline & & P15 peptide based & ePTFE & $\begin{array}{l}\text { Smaller thicknesses of neointimal hyperplasia; enhanced } \\
\text { endothelialization }\end{array}$ & [236] \\
\hline & & $\begin{array}{l}\text { Growth factor -reduced } \\
\text { Matrigel }^{\mathrm{TM}} \text {-containing VEGF }\end{array}$ & ePTFE & Increased EC rate, increased myointimal hyperplasia & [237] \\
\hline & & Hyaluronic acid based & PCL & Higher bulk porosity and cell permeability & [238] \\
\hline & & VEGF based & PEA, PMA & $\begin{array}{l}\text { Promoting vascularization in regenerative medicine } \\
\text { applications }\end{array}$ & [159] \\
\hline
\end{tabular}


Table 1. Cont

\begin{tabular}{|c|c|c|c|c|c|}
\hline Tissue Type & Tissue or Organ & Coating for Specific Tissue Type & Polymer as the Base of Coating & Functional Element of the Coating & Refs. \\
\hline \multirow{8}{*}{$\begin{array}{l}\text { Nerve } \\
\text { (Section 5) }\end{array}$} & \multirow{8}{*}{$\begin{array}{c}\text { Nerve } \\
\text { (Section 5) }\end{array}$} & Laminin peptides & Chitosan & $\begin{array}{l}\text { Enhancer of the attachment of neural cell, differentiation; } \\
\text { outgrowth of neurites }\end{array}$ & [239] \\
\hline & & Platelet-rich plasma & PLA/GTNF & Healing improvement & [240] \\
\hline & & $\begin{array}{l}\text { ( } \gamma \text {-glycidoxypropyltrimethoxysilane } \\
\text { (GPTMS) }\end{array}$ & Chitosan & Improving mechanical strength & [241] \\
\hline & & $\begin{array}{l}\text { Poly-L-lysine, poly-L-ornithine, } \\
\text { laminin, collagen }\end{array}$ & Poly (sialic acid) & Mechano compatibility; cell adhesive property & [242] \\
\hline & & $\begin{array}{l}\text { Collagen type I; EDC/NHS activation } \\
\text { (amino groups) }\end{array}$ & P(MMA-co-AA) & Promotion of cell attachment, spreading, and viability & [243] \\
\hline & & Polypyrrole (PPy) & PCL, PLA & Cell density, cell spread, & {$[244,245]$} \\
\hline & & RGD peptide based & PEG-heparin hybrid gel & $\begin{array}{l}\text { Differentiation \& propagation of NSCs; outgrowth of } \\
\text { axon dendrites }\end{array}$ & {$[245,246]$} \\
\hline & & Laminin based & Collagen type I & Bridging peripheral nerve gaps & {$[245,247]$} \\
\hline \multirow{8}{*}{$\begin{array}{l}\text { Visceral } \\
\text { (Section 6) }\end{array}$} & \multirow{2}{*}{$\begin{array}{c}\text { Lung } \\
\text { (Section 6.1) }\end{array}$} & Gelatin based & $\begin{array}{l}\text { PCL } \\
\text { PGA }\end{array}$ & $\begin{array}{l}\text { Adherence of NCI-H292 cells; tuning mechanical } \\
\text { properties of materials }\end{array}$ & {$[177,178,248]$} \\
\hline & & bFGF and AA2P based & PGA/PLA & $\begin{array}{l}\text { Improving cells adhesion and stimulates cells } \\
\text { proliferation and differentiation }\end{array}$ & [249] \\
\hline & \multirow{2}{*}{$\begin{array}{l}\text { Kidney } \\
\text { (Section 6.2) }\end{array}$} & $\mathrm{Mg}(\mathrm{OH})_{2}$ and acellular ECM & PLGA & $\begin{array}{l}\text { Neutralization of the effects induced by degradation of } \\
\text { PLGA products, suppression of inflammatory reactions }\end{array}$ & [186] \\
\hline & & 1-DOPA and collagen IV & PCL & Improving cells adhesion and proliferation & [250] \\
\hline & \multirow{4}{*}{$\begin{array}{c}\text { Liver } \\
\text { (Section 6.3) }\end{array}$} & FCM-molecules & PLA & \multirow{2}{*}{$\begin{array}{l}\text { Microenvironment manipulation; changes of gene } \\
\text { expression, protein contents, and cell adherence }\end{array}$} & [251] \\
\hline & & & PCL & & [252] \\
\hline & & HGF based & Gelatin & $\begin{array}{l}\text { Controlled release for enhancement of the in vivo } \\
\text { therapeutic effects }\end{array}$ & \\
\hline & & RGD and YIGSR based & PCL and PLA & Improved hepatocyte adhesion & [196] \\
\hline
\end{tabular}


Table 1. Cont

\begin{tabular}{|c|c|c|c|c|c|}
\hline Tissue Type & Tissue or Organ & Coating for Specific Tissue Type & Polymer as the Base of Coating & Functional Element of the Coating & Refs. \\
\hline \multirow{16}{*}{$\begin{array}{l}\text { Musculoskeletal } \\
\quad \text { (Section 7) }\end{array}$} & \multirow{2}{*}{$\begin{array}{l}\text { Cardiac muscles } \\
\text { (Section 7.1) }\end{array}$} & bFGF based & PLGA & Neovascular formation & [253] \\
\hline & & Laminin based & PU & Improving cells adhesion & [254] \\
\hline & \multirow{6}{*}{$\begin{array}{l}\text { Skeletal muscles } \\
\quad \text { (Section 7.2) }\end{array}$} & Collagen-chitosan based & PDMS & Improving cell adhesion & [255] \\
\hline & & Collagen-I based & Polyacrylamide & Improving cell adhesion & {$[256,257]$} \\
\hline & & Laminin and RGD based & PEG & Improving cells adhesion & {$[258,259]$} \\
\hline & & RGD based & Alginate & Improving cells adhesion & [75] \\
\hline & & Fibrin based & PLG & Anastomosis with the host vasculature and angiogenesis & [209] \\
\hline & & Agrin or laminin based & Alginate & Exhibited acetylcholine receptor (AChR) clustering & {$[210,211]$} \\
\hline & \multirow{6}{*}{$\begin{array}{l}\text { Cartilage } \\
\text { (Section 7.3) }\end{array}$} & Hyaluronic acid based & PLGA & Improving cell migration and proliferation & [45] \\
\hline & & Platelet-rich-plasma based & PGA & Homogeneous hyaline-like cartilage tissue repair. & [260] \\
\hline & & Fibrinogen based & PEG & Improving cells adhesion & [261] \\
\hline & & Fibrin based & PGA & $\begin{array}{l}\text { Bio-sustainability of cell-based tissue regeneration } \\
\text { (without in vitro cultivation) }\end{array}$ & {$[262,263]$} \\
\hline & & Hyaluronic acid based & Alginate & Improving cell migration and proliferation & {$[263,264]$} \\
\hline & & Tri-(calcium phosphate) based & PLGA & Improving osteochondral composition & {$[263,265]$} \\
\hline & \multirow{2}{*}{$\begin{array}{c}\text { Bones } \\
\text { (Section 7.4) }\end{array}$} & $\mathrm{CaCO}_{3} / \mathrm{PHB} \& \mathrm{PHBV}$ based & PHB and PHBV & Improving cells adhesion and ossification & [266] \\
\hline & & $\mathrm{CaCO}_{3}$ with loaded ALP & Alginate & Improving cells adhesion and ossification & [228] \\
\hline
\end{tabular}




\section{Conclusions and Outlook}

In summary, tissue engineering is an important interdisciplinary and multidisciplinary research area with an explosive growth potential. Two most important building blocks here are polymer-based and hybrid biomaterials. Innovations in the design of coatings, progress in their imaging and characterization as well as availability of new materials open opportunities for custom-tuned biomaterials suited for various tissue engineering sub-areas. Some of these materials are purely polymeric, yet they have been also shown to be directly applicable in tissues engineering. These polymeric materials are complementary to the so-called hybrids incorporating inorganic constituents together with organic (polymeric) matrix. These hybrids are increasingly used for matching the properties of various tissues and enabling thus the so-called "one-matches-all" concept. This refers to one or similar materials, which can be applied in various and most importantly different areas of tissue engineering. Besides inorganic particles or capsules in such hybrid coatings enable release of relevant bio-molecules. It can be alluded that although such tissues as tendon, skin, vascular and nerve tissue, lung, kidney, liver, cardiac and skeletal muscles, cartilage, bones) are very different, they can be all targeted with the same material base. An additional important functionality of hybrids is controlled release of encapsulated biomolecules.

Future directions of research are expected to experience further merger of biomaterials with bio-medical sciences, wherein scientists working in the former areas will be looking in more details to the needs in the bio-medicine. By the same token, doctors and biologists would benefit from new solutions and novel formulations offered by material scientists. Information on the properties of different tissues and state-of-art in their respective areas, overviewed here, will be helpful to design new materials and knowing already available ones. Further integration of biomaterials with tissue and organs will likely experience further interest to understanding their mechanical properties, surface functionalization, possibility of $3 \mathrm{D}$ and $4 \mathrm{D}$ printing technologies, physiological behavior. Additional in-vivo tests would play an increasing role in further integrating these two types of materials (organics and inorganics) and these two areas.

Author Contributions: Writing—original draft preparation, A.A.; writing—review and editing, B.P. and A.G.S. All authors have read and agreed to the published version of the manuscript.

Funding: This research was funded by BOF UGent (01IO3618, BOF14/IOP/003, BAS094-18), FWO Flanders $(\mathrm{G} 043219,1524618 \mathrm{~N})$, and ERA-Net RusPlus. AA thanks the support of the program "Global Education". BVP is a post-doctoral fellow of FWO.

Conflicts of Interest: The authors declare no conflict of interest.

\section{References}

1. Blanpain, C.; Fuchs, E. Plasticity of epithelial stem cells in tissue regeneration. Science (80-) 2014, 344, 1242281. [CrossRef] [PubMed]

2. Mobaraki, M.; Abbasi, R.; Vandchali, S.O.; Ghaffari, M.; Moztarzadeh, F.; Mozafari, M. Corneal repair and regeneration: Current concepts and future directions. Front. Bioeng. Biotechnol. 2019, 7. [CrossRef] [PubMed]

3. Takeo, M.; Lee, W.; Ito, M. Wound healing and skin regeneration. Cold Spring Harb. Perspect. Med. 2015, 5, a023267. [CrossRef] [PubMed]

4. Michalopoulos, G.K. Liver regeneration. J. Cell. Physiol. 2007, 213, 286-300. [CrossRef]

5. Daly, A.C.; Riley, L.; Segura, T.; Burdick, J.A. Hydrogel microparticles for biomedical applications. Nat. Rev. Mater. 2020, 5, 20-43. [CrossRef]

6. Vining, K.H.; Mooney, D.J. Mechanical forces direct stem cell behaviour in development and regeneration. Nat. Rev. Mol. Cell Biol. 2017, 18, 728-742. [CrossRef]

7. Mitrousis, N.; Fokina, A.; Shoichet, M.S. Biomaterials for cell transplantation. Nat. Rev. Mater. 2018, 3, 441-456. [CrossRef]

8. Park, J.H.; Hong, J.M.; Ju, Y.M.; Jung, J.W.; Kang, H.W.; Lee, S.J.; Yoo, J.J.; Kim, S.W.; Kim, S.H.; Cho, D.W. A novel tissue-engineered trachea with a mechanical behavior similar to native trachea. Biomaterials 2015, 62, 106-115. [CrossRef] 
9. Mano, J.F.; Sousa, R.A.; Boesel, L.F.; Neves, N.M.; Reis, R.L. Bioinert, biodegradable and injectable polymeric matrix composites for hard tissue replacement: State of the art and recent developments. Compos. Sci. Technol. 2004, 64, 789-817. [CrossRef]

10. Osathanon, T.; Pavasant, P.; Giachelli, C. Notch Signaling Biomaterials and Tissue Regeneration; Pan Stanford: Singapore, 2014; ISBN 9789814411684.

11. Li, D.; Liu, T.; Yu, X.; Wu, D.; Su, Z. Fabrication of graphene-biomacromolecule hybrid materials for tissue engineering application. Polym. Chem. 2017, 8, 4309-4321. [CrossRef]

12. Zhang, K.; Wang, S.; Zhou, C.; Cheng, L.; Gao, X.; Xie, X.; Sun, J.; Wang, H.; Weir, M.D.; Reynolds, M.A.; et al. Advanced smart biomaterials and constructs for hard tissue engineering and regeneration. Bone Res. 2018, 6 , 31. [CrossRef] [PubMed]

13. Delcea, M.; Möhwald, H.; Skirtach, A.G. Stimuli-responsive LbL capsules and nanoshells for drug delivery. Adv. Drug Deliv. Rev. 2011, 63, 730-747. [CrossRef] [PubMed]

14. Vidiasheva, I.V.; Abalymov, A.A.; Kurochkin, M.A.; Mayorova, O.A.; Lomova, M.V.; German, S.V.; Khalenkow, D.N.; Zharkov, M.N.; Gorin, D.A.; Skirtach, A.G.; et al. Transfer of cells with uptaken nanocomposite, magnetite-nanoparticle functionalized capsules with electromagnetic tweezers. Biomater. Sci. 2018, 6, 2219-2229. [CrossRef] [PubMed]

15. Parakhonskiy, B.V.; Abalymov, A.; Ivanova, A.; Khalenkow, D.; Skirtach, A.G. Magnetic and silver nanoparticle functionalized calcium carbonate particles-Dual functionality of versatile, movable delivery carriers which can surface-enhance Raman signals. J. Appl. Phys. 2019, 126, 203102. [CrossRef]

16. Marchenko, I.; Yashchenok, A.; Borodina, T.; Bukreeva, T.; Konrad, M.; Möhwald, H.; Skirtach, A. Controlled enzyme-catalyzed degradation of polymeric capsules templated on $\mathrm{CaCO}_{3}$ : Influence of the number of LbL layers, conditions of degradation, and disassembly of multicompartments. J. Control. Release 2012, 162, 599-605. [CrossRef]

17. Zhang, C.; Pansare, V.J.; Prud'Homme, R.K.; Priestley, R.D. Flash nanoprecipitation of polystyrene nanoparticles. Soft Matter 2012, 8, 86-93. [CrossRef]

18. Yang, Y.; Wei, Z.; Wang, C.; Tong, Z. Versatile fabrication of nanocomposite microcapsules with controlled shell thickness and low permeability. ACS Appl. Mater. Interfaces 2013, 5, 2495-2502. [CrossRef]

19. Volodkin, D.; Skirtach, A.; Möhwald, H. Bioapplications of light-sensitive polymer films and capsules assembled using the layer-by-layer technique. Polym. Int. 2012, 61, 673-679. [CrossRef]

20. Lengert, E.; Saveleva, M.; Abalymov, A.; Atkin, V.; Wuytens, P.C.; Kamyshinsky, R.; Vasiliev, A.L.; Gorin, D.A.; Sukhorukov, G.B.; Skirtach, A.G.; et al. Silver Alginate Hydrogel Micro- and Nanocontainers for Theranostics: Synthesis, Encapsulation, Remote Release, and Detection. ACS Appl. Mater. Interfaces 2017, 9, 21949-21958. [CrossRef]

21. Skirtach, A.G.; Dejugnat, C.; Braun, D.; Susha, A.S.; Rogach, A.L.; Parak, W.J.; Möhwald, H.; Sukhorukovt, G.B. The role of metal nanoparticles in remote release of encapsulated materials. Nano Lett. 2005, 5, 1371-1377. [CrossRef]

22. Parakhonskiy, B.V.; Gorin, D.A.; Bäumler, H.; Skirtach, A.G. Temperature rise around nanoparticles: Applications for polyelectrolyte multilayer capsules. J. Therm. Anal. Calorim. 2017, 127, 895-904. [CrossRef]

23. Koryakina, I.; Kuznetsova, D.S.; Zuev, D.A.; Milichko, V.A.; Timin, A.S.; Zyuzin, M.V. Optically responsive delivery platforms: From the design considerations to biomedical applications. Nanophotonics 2020, 9, 39-74. [CrossRef]

24. Wei, J.; Cai, J.; Li, Y.; Wu, B.; Gong, X.; Ngai, T. Investigation of cell behaviors on thermo-responsive PNIPAM microgel films. Colloids Surf. B Biointerfaces 2015, 132, 202-207. [CrossRef]

25. Saveleva, M.S.; Eftekhari, K.; Abalymov, A.; Douglas, T.E.L.; Volodkin, D.; Parakhonskiy, B.V.; Skirtach, A.G. Hierarchy of hybrid materials-the place of inorganics-in-organics in it, their composition and applications. Front. Chem. 2019, 7, 1-21. [CrossRef]

26. Wuytens, P.; Parakhonskiy, B.; Yashchenok, A.; Winterhalter, M.; Skirtach, A. Pharmacological aspects of release from microcapsules-From polymeric multilayers to lipid membranes. Curr. Opin. Pharmacol. 2014, 18, 129-140. [CrossRef] [PubMed]

27. Tokarev, I.; Minko, S. Preprogrammed Dynamic Microstructured Polymer Interfaces. Adv. Funct. Mater. 2020, 30, 1903478. [CrossRef]

28. Feeney, M.J.; Thomas, S.W. Combining Top-Down and Bottom-Up with Photodegradable Layer-by-Layer Films. Langmuir 2019, 35, 13791-13804. [CrossRef] 
29. Skorb, E.; Volkova, A.; Andreeva, D. Layer-by-Layer Assembled Hybrid Materials for Sustainable Applications. Curr. Org. Chem. 2014, 18, 2315-2333. [CrossRef]

30. Douglas, T.E.L.; Schietse, J.; Zima, A.; Gorodzha, S.; Parakhonskiy, B.V.; KhaleNkow, D.; Shkarin, R.; Ivanova, A.; Baumbach, T.; Weinhardt, V.; et al. Novel self-gelling injectable hydrogel/alpha-tricalcium phosphate composites for bone regeneration: Physiochemical and microcomputer tomographical characterization. J. Biomed. Mater. Res. Part A 2018, 106, 822-828. [CrossRef]

31. Abalymov, A.A.; Verkhovskii, R.A.; Novoselova, M.V.; Parakhonskiy, B.V.; Gorin, D.A.; Yashchenok, A.M.; Sukhorukov, G.B. Live-Cell Imaging by Confocal Raman and Fluorescence Microscopy Recognizes the Crystal Structure of Calcium Carbonate Particles in HeLa Cells. Biotechnol. J. 2018, 13, 1800071. [CrossRef]

32. Schmidt, S.; Madaboosi, N.; Uhlig, K.; Köhler, D.; Skirtach, A.; Duschl, C.; Möhwald, H.; Volodkin, D.V. Control of cell adhesion by mechanical reinforcement of soft polyelectrolyte films with nanoparticles. Langmuir 2012, 28, 7249-7257. [CrossRef] [PubMed]

33. Parakhonskiy, B.V.; Bedard, M.F.; Bukreeva, T.V.; Sukhorukov, G.B.; Möhwald, H.; Skirtach, A.G. Nanoparticles on polyelectrolytes at low concentration: Controlling concentration and size. J. Phys. Chem. C 2010, 114, 1996-2002. [CrossRef]

34. Volodkin, D.V.; Delcea, M.; Möhwald, H.; Skirtach, A.G. Remote near-IR light activation of a hyaluronic acid/poly(1-lysine) multilayered film and film-entrapped microcapsules. ACS Appl. Mater. Interfaces 2009, 1, 1705-1710. [CrossRef] [PubMed]

35. Lavalle, P.; Picart, C.; Mutterer, J.; Gergely, C.; Reiss, H.; Voegel, J.C.; Senger, B.; Schaaf, P. Modeling the Buildup of Polyelectrolyte Multilayer Films Having Exponential Growth. J. Phys. Chem. B 2004, 108, 635-648. [CrossRef]

36. Parakhonskiy, B.V.; Yashchenok, A.M.; Möhwald, H.; Volodkin, D.; Skirtach, A.G. Release from Polyelectrolyte Multilayer Capsules in Solution and on Polymeric Surfaces. Adv. Mater. Interfaces 2017, 4, 1600273. [CrossRef]

37. Santo, V.E.; Gomes, M.E.; Mano, J.F.; Reis, R.L. Controlled release strategies for bone, cartilage, and osteochondral engineering-part i: Recapitulation of native tissue healing and variables for the design of delivery systems. Tissue Eng. Part B Rev. 2013, 19, 308-326. [CrossRef]

38. Facca, S.; Cortez, C.; Mendoza-Palomares, C.; Messadeq, N.; Dierich, A.; Johnston, A.P.R.; Mainard, D.; Voegel, J.C.; Caruso, F.; Benkirane-Jessel, N. Active multilayered capsules for in vivo bone formation. Proc. Natl. Acad. Sci. USA 2010, 107, 3406-3411. [CrossRef]

39. Zhang, Y.; Wang, X.; Cao, M. Confinedly implanted $\mathrm{NiFe}_{2} \mathrm{O}_{4}-\mathrm{rGO}$ : Cluster tailoring and highly tunable electromagnetic properties for selective-frequency microwave absorption. Nano Res. 2018, 11, 1426-1436. [CrossRef]

40. McShane, M.J.; Brown, J.Q.; Guice, K.B.; Lvov, Y.M. Polyelectrolyte Microshells as Carriers for Fluorescent Sensors: Loading and Sensing Properties of a Ruthenium-Based Oxygen Indicator. J. Nanosci. Nanotechnol. 2002, 2, 411-416. [CrossRef]

41. Del Mercato, L.L.; Abbasi, A.Z.; Ochs, M.; Parak, W.J. Multiplexed sensing of ions with barcoded polyelectrolyte capsules. ACS Nano 2011, 5, 9668-9674. [CrossRef]

42. Dubreuil, F.; Elsner, N.; Fery, A. Elastic properties of polyelectrolyte capsules studied by atomic-force microscopy and RICM. Eur. Phys. J. E 2003, 12, 215-221. [CrossRef] [PubMed]

43. Fernandes, P.A.L.; Delcea, M.; Skirtach, A.G.; Möhwald, H.; Fery, A. Quantification of release from microcapsules upon mechanical deformation with AFM. Soft Matter 2010, 6, 1879-1883. [CrossRef]

44. Kozlovskaya, V.; Xue, B.; Kharlampieva, E. Shape-adaptable polymeric particles for controlled delivery. Macromolecules 2016, 49, 8373-8386. [CrossRef]

45. Siclari, A.; Mascaro, G.; Kaps, C.; Boux, E. A 5-Year Follow-Up After Cartilage Repair in the Knee Using a Platelet-Rich Plasma-Immersed Polymer-Based Implant. Open Orthop. J. 2014, 8, 346-354. [CrossRef] [PubMed]

46. Savioli Lopes, M.; Jardini, A.L.; Maciel Filho, R. Poly (lactic acid) production for tissue engineering applications. Procedia Eng. 2012, 42, 1402-1413. [CrossRef]

47. Gentile, P.; McColgan-Bannon, K.; Gianone, N.C.; Sefat, F.; Dalgarno, K.; Ferreira, A.M. Biosynthetic PCL-graft-collagen bulk material for tissue engineering applications. Materials 2017, 10, 693. [CrossRef] [PubMed] 
48. Sehgal, R.R.; Roohani-Esfahani, S.I.; Zreiqat, H.; Banerjee, R. Nanostructured gellan and xanthan hydrogel depot integrated within a baghdadite scaffold augments bone regeneration. J. Tissue Eng. Regen. Med. 2017, 11, 1195-1211. [CrossRef] [PubMed]

49. Duan, X.; McLaughlin, C.; Griffith, M.; Sheardown, H. Biofunctionalization of collagen for improved biological response: Scaffolds for corneal tissue engineering. Biomaterials 2007, 28, 78-88. [CrossRef]

50. Douglas, T.E.L.; Łapa, A.; Samal, S.K.; Declercq, H.A.; Schaubroeck, D.; Mendes, A.C.; der Voort, P.V.; Dokupil, A.; Plis, A.; De Schamphelaere, K.; et al. Enzymatic, urease-mediated mineralization of gellan gum hydrogel with calcium carbonate, magnesium-enriched calcium carbonate and magnesium carbonate for bone regeneration applications. J. Tissue Eng. Regen. Med. 2017, 11, 3556-3566. [CrossRef]

51. He, Y.; Jin, Y.; Wang, X.; Yao, S.; Li, Y.; Wu, Q.; Ma, G.; Cui, F.; Liu, H. An antimicrobial peptide-loaded gelatin/chitosan nanofibrous membrane fabricated by sequential layer-by-layer electrospinning and electrospraying techniques. Nanomaterials 2018, 8, 327. [CrossRef]

52. Armentano, I.; Puglia, D.; Luzi, F.; Arciola, C.R.; Morena, F.; Martino, S.; Torre, L. Nanocomposites based on biodegradable polymers. Materials 2018, 11, 795. [CrossRef] [PubMed]

53. Engler, A.J.; Sen, S.; Sweeney, H.L.; Discher, D.E. Matrix Elasticity Directs Stem Cell Lineage Specification. Cell 2006, 126, 677-689. [CrossRef] [PubMed]

54. Luckachan, G.E.; Pillai, C.K.S. Biodegradable Polymers- A Review on Recent Trends and Emerging Perspectives. J. Polym. Environ. 2011, 19, 637-676. [CrossRef]

55. Gorth, D.; Webster, T.J. Matrices for tissue engineering and regenerative medicine. In Biomaterials for Artificial Organs; Elsevier: Amsterdam, The Netherlands, 2010; pp. 270-286, ISBN 9781845696535.

56. Boland, E.D.; Wnek, G.E.; Simpson, D.G.; Pawlowski, K.J.; Bowlin, G.L. Tailoring tissue engineering scaffolds using electrostatic processing techniques: A study of poly(glycolic acid) electrospinning. J. Macromol. Sci. Pure Appl. Chem. 2001, 38, 1231-1243. [CrossRef]

57. Kobayashi, H.; Terada, D.; Yokoyama, Y.; Moon, D.W.; Yasuda, Y.; Koyama, H.; Takato, T. Vascular-inducing poly(glycolic acid)-collagen nanocomposite-fiber scaffold. J. Biomed. Nanotechnol. 2013, 9, 1318-1326. [CrossRef] [PubMed]

58. Patrascu, J.M.; Krüger, J.P.; Böss, H.G.; Ketzmar, A.K.; Freymann, U.; Sittinger, M.; Notter, M.; Endres, M.; Kaps, C. Polyglycolic acid-hyaluronan scaffolds loaded with bone marrow-derived mesenchymal stem cells show chondrogenic differentiation in vitro and cartilage repair in the rabbit model. J. Biomed. Mater. Res. Part B Appl. Biomater. 2013, 101, 1310-1320. [CrossRef] [PubMed]

59. Casalini, T.; Rossi, F.; Castrovinci, A.; Perale, G. A Perspective on Polylactic Acid-Based Polymers Use for Nanoparticles Synthesis and Applications. Front. Bioeng. Biotechnol. 2019, 7. [CrossRef]

60. Middleton, J.C.; Tipton, A.J. Synthetic biodegradable polymers as orthopedic devices. Biomaterials 2000, 21, 2335-2346. [CrossRef]

61. Lin, C.-C.; Fu, S.-J.; Lin, Y.-C.; Yang, I.-K.; Gu, Y. Chitosan-coated electrospun PLA fibers for rapid mineralization of calcium phosphate. Int. J. Biol. Macromol. 2014, 68, 39-47. [CrossRef]

62. Mi, H.Y.; Salick, M.R.; Jing, X.; Jacques, B.R.; Crone, W.C.; Peng, X.F.; Turng, L.S. Characterization of thermoplastic polyurethane/polylactic acid (TPU/PLA) tissue engineering scaffolds fabricated by microcellular injection molding. Mater. Sci. Eng. C 2013, 33, 4767-4776. [CrossRef]

63. Malikmammadov, E.; Tanir, T.E.; Kiziltay, A.; Hasirci, V.; Hasirci, N. PCL and PCL-based materials in biomedical applications. J. Biomater. Sci. Polym. Ed. 2018, 29, 863-893. [CrossRef] [PubMed]

64. Mochane, M.J.; Motsoeneng, T.S.; Sadiku, E.R.; Mokhena, T.C.; Sefadi, J.S. Morphology and properties of electrospun PCL and its composites for medical applications: A mini review. Appl. Sci. 2019, 9, 2205. [CrossRef]

65. Patrício, T.; Domingos, M.; Gloria, A.; Bártolo, P. Characterisation of PCL and PCL/PLA Scaffolds for Tissue Engineering. Procedia CIRP 2013, 5, 110-114. [CrossRef]

66. Fuller, K.P.; Gaspar, D.; Delgado, L.M.; Shoseyov, O.; Zeugolis, D.I. In vitro and preclinical characterisation of compressed, macro-porous and collagen coated poly- $\epsilon$-caprolactone electro-spun scaffolds. Biomed. Mater. 2019, 14, 055007. [CrossRef] [PubMed]

67. Savelyeva, M.S.; Abalymov, A.A.; Lyubun, G.P.; Vidyasheva, I.V.; Yashchenok, A.M.; Douglas, T.E.L.; Gorin, D.A.; Parakhonskiy, B.V. Vaterite coatings on electrospun polymeric fibers for biomedical applications. J. Biomed. Mater. Res. Part A 2017, 105, 94-103. [CrossRef] 
68. Li, X.; Xie, J.; Lipner, J.; Yuan, X.; Thomopoulos, S.; Xia, Y. Nanofiber scaffolds with gradations in mineral content for mimicking the tendon-to-bone insertion site. Nano Lett. 2009, 9, 2763-2768. [CrossRef]

69. Akter, F.; Berhan-Tewolde, L.; De Mel, A. Lung Tissue Engineering; Elsevier Inc.: Amsterdam, The Netherlands, 2016; ISBN 9780128092286.

70. Schmidt, S.; Zeiser, M.; Hellweg, T.; Duschl, C.; Fery, A.; Möhwald, H. Adhesion and mechanical properties of PNIPAM microgel films and their potential use as switchable cell culture substrates. Adv. Funct. Mater. 2010, 20, 3235-3243. [CrossRef]

71. Lee, K.Y.; Mooney, D.J. Alginate: Properties and biomedical applications. Prog. Polym. Sci. 2012, 37, $106-126$. [CrossRef]

72. Andersen, T.; Auk-Emblem, P.; Dornish, M. 3D Cell Culture in Alginate Hydrogels. Microarrays 2015, 4, 133-161. [CrossRef]

73. Venkatesan, J.; Bhatnagar, I.; Manivasagan, P.; Kang, K.H.; Kim, S.K. Alginate composites for bone tissue engineering: A review. Int. J. Biol. Macromol. 2015, 72, 269-281. [CrossRef]

74. MacHida-Sano, I.; Matsuda, Y.; Namiki, H. In vitro adhesion of human dermal fibroblasts on iron cross-linked alginate films. Biomed. Mater. 2009, 4, 025008. [CrossRef] [PubMed]

75. Augst, A.D.; Kong, H.J.; Mooney, D.J. Alginate hydrogels as biomaterials. Macromol. Biosci. 2006, 6, 623-633. [CrossRef] [PubMed]

76. Antoine, E.E.; Vlachos, P.P.; Rylander, M.N. Review of collagen i hydrogels for bioengineered tissue microenvironments: Characterization of mechanics, structure, and transport. Tissue Eng. Part B Rev. 2014, 20, 683-696. [CrossRef] [PubMed]

77. Trappmann, B.; Gautrot, J.E.; Connelly, J.T.; Strange, D.G.T.; Li, Y.; Oyen, M.L.; Cohen Stuart, M.A.; Boehm, H.; Li, B.; Vogel, V.; et al. Extracellular-matrix tethering regulates stem-cell fate. Nat. Mater. 2012, 11, 642-649. [CrossRef]

78. Racine, L.; Texier, I.; Auzély-Velty, R. Chitosan-based hydrogels: Recent design concepts to tailor properties and functions. Polym. Int. 2017, 66, 981-998. [CrossRef]

79. Chander, V.; Singh, A.K.; Gangenahalli, G. Cell encapsulation potential of chitosan-alginate electrostatic complex in preventing natural killer and CD8 + cell-mediated cytotoxicity: An in vitro experimental study. J. Microencapsul. 2018, 35, 522-532. [CrossRef]

80. Collins, M.N.; Birkinshaw, C. Hyaluronic acid based scaffolds for tissue engineering-A review. Carbohydr. Polym. 2013, 92, 1262-1279. [CrossRef]

81. Fakhari, A.; Berkland, C. Applications and emerging trends of hyaluronic acid in tissue engineering, as a dermal filler and in osteoarthritis treatment. Acta Biomater. 2013, 9, 7081-7092. [CrossRef]

82. Bian, L.; Hou, C.; Tous, E.; Rai, R.; Mauck, R.L.; Burdick, J.A. The influence of hyaluronic acid hydrogel crosslinking density and macromolecular diffusivity on human MSC chondrogenesis and hypertrophy. Biomaterials 2013, 34, 413-421. [CrossRef]

83. Benkirane-Jessel, N.; Lavalle, P.; Hübsch, E.; Holl, V.; Senger, B.; Haïkel, Y.; Voegel, J.C.; Ogier, J.; Schaaf, P. Short-time tuning of the biological activity of functionalized polyelectrolyte multilayers. Adv. Funct. Mater. 2005, 15, 648-654. [CrossRef]

84. Novotna, K.; Havelka, P.; Sopuch, T.; Kolarova, K.; Vosmanska, V.; Lisa, V.; Svorcik, V.; Bacakova, L. Cellulose-based materials as scaffolds for tissue engineering. Cellulose 2013, 20, 2263-2278. [CrossRef]

85. Märtson, M.; Viljanto, J.; Hurme, T.; Laippala, P.; Saukko, P. Is cellulose sponge degradable or stable as implantation material? An in vivo subcutaneous study in the rat. Biomaterials 1999, 20, 1989-1995. [CrossRef]

86. Brugnoni, M.; Nickel, A.C.; Kröger, L.C.; Scotti, A.; Pich, A.; Leonhard, K.; Richtering, W. Synthesis and structure of deuterated ultra-low cross-linked poly(N-isopropylacrylamide) microgels. Polym. Chem. 2019, 10, 2397-2405. [CrossRef]

87. Tokarev, I.; Minko, S. Stimuli-responsive porous hydrogels at interfaces for molecular filtration, separation, controlled release, and gating in capsules and membranes. Adv. Mater. 2010, 22, 3446-3462. [CrossRef] [PubMed]

88. Douglas, T.E.L.; Dziadek, M.; Schietse, J.; Boone, M.; Declercq, H.A.; Coenye, T.; Vanhoorne, V.; Vervaet, C.; Balcaen, L.; Buchweitz, M.; et al. Pectin-bioactive glass self-gelling, injectable composites with high antibacterial activity. Carbohydr. Polym. 2019, 205, 427-436. [CrossRef] [PubMed]

89. Decher, G. Fuzzy nanoassemblies: Toward layered polymeric multicomposites. Science (80-) 1997, 277, 1232-1237. [CrossRef] 
90. Richert, L.; Boulmedais, F.; Lavalle, P.; Mutterer, J.; Ferreux, E.; Decher, G.; Schaaf, P.; Voegel, J.-C.; Picart, C. Improvement of Stability and Cell Adhesion Properties of Polyelectrolyte Multilayer Films by Chemical Cross-Linking. Biomacromolecules 2004, 5, 284-294. [CrossRef]

91. Steitz, R.; Jaeger, W.; Klitzing, R.V. Influence of Charge Density and Ionic Strength on the Multilayer Formation of Strong Polyelectrolytes. Langmuir 2001, 17, 4471-4474. [CrossRef]

92. Erwin, A.J.; Xu, W.; He, H.; Matyjaszewski, K.; Tsukruk, V.V. Linear and Star Poly(ionic liquid) Assemblies: Surface Monolayers and Multilayers. Langmuir 2017, 33, 3187-3199. [CrossRef]

93. Delgado, J.D.; Schlenoff, J.B. Polyelectrolyte Complex Films from Blends Versus Copolymers. Macromolecules 2019, 52, 7812-7820. [CrossRef]

94. Zhao, S.; Caruso, F.; Dähne, L.; Decher, G.; De Geest, B.G.; Fan, J.; Feliu, N.; Gogotsi, Y.; Hammond, P.T.; Hersam, M.C.; et al. The Future of Layer-by-Layer Assembly: A Tribute to ACS Nano Associate Editor Helmuth Möhwald. ACS Nano 2019, 13, 6151-6169. [CrossRef] [PubMed]

95. Gilbert, J.B.; Rubner, M.F.; Cohen, R.E. Depth-profiling X-ray photoelectron spectroscopy (XPS) analysis of interlayer diffusion in polyelectrolyte multilayers. Proc. Natl. Acad. Sci. USA 2013, 110, 6651-6656. [CrossRef] [PubMed]

96. Selin, V.; Ankner, J.; Sukhishvili, S. Ionically Paired Layer-by-Layer Hydrogels: Water and Polyelectrolyte Uptake Controlled by Deposition Time. Gels 2018, 4, 7. [CrossRef]

97. Ryzhkov, N.V.; Andreeva, D.V.; Skorb, E.V. Coupling pH-Regulated Multilayers with Inorganic Surfaces for Bionic Devices and Infochemistry. Langmuir 2019, 35, 8543-8556. [CrossRef] [PubMed]

98. Zhang, J.; Wang, D.; Jiang, X.; He, L.; Fu, L.; Zhao, Y.; Wang, Y.; Mo, H.; Shen, J. Multistructured vascular patches constructed via layer-by-layer self-assembly of heparin and chitosan for vascular tissue engineering applications. Chem. Eng. J. 2019, 370, 1057-1067. [CrossRef]

99. Monge, C.; Almodóvar, J.; Boudou, T.; Picart, C. Spatio-temporal control of LbL films for biomedical applications: From 2D to 3D. Adv. Healthc. Mater. 2015, 4, 811-830. [CrossRef] [PubMed]

100. Zhang, L.; Chen, H.; Sun, J.; Shen, J. Layer-by-layer deposition of poly(diallyldimethylammonium chloride) and sodium silicate multilayers on silica-sphere-coated substrate-facile method to prepare a superhydrophobic surface. Chem. Mater. 2007, 19, 948-953. [CrossRef]

101. Crouzier, T.; Ren, K.; Nicolas, C.; Roy, C.; Picart, C. Layer-by-layer films as a biomimetic reservoir for rhBMP-2 delivery: Controlled differentiation of myoblasts to osteoblasts. Small 2009, 5, 598-608. [CrossRef]

102. Chen, X.; Cortez-Jugo, C.; Choi, G.H.; Björnmalm, M.; Dai, Y.; Yoo, P.J.; Caruso, F. Patterned Poly(dopamine) films for enhanced cell adhesion. Bioconjug. Chem. 2017, 28, 75-80. [CrossRef]

103. Berg, M.C.; Yang, S.Y.; Hammond, P.T.; Rubner, M.F. Controlling Mammalian Cell Interactions on Patterned Polyelectrolyte Multilayer Surfaces. Langmuir 2004, 20, 1362-1368. [CrossRef]

104. Blacklock, J.; Vetter, A.; Lankenau, A.; Oupický, D.; Möhwald, H. Tuning the mechanical properties of bioreducible multilayer films for improved cell adhesion and transfection activity. Biomaterials 2010, 31, 7167-7174. [CrossRef] [PubMed]

105. Skirtach, A.G.; Yashchenok, A.M.; Möhwald, H. Encapsulation, release and applications of LbL polyelectrolyte multilayer capsules. Chem. Commun. 2011, 47, 12736-12746. [CrossRef] [PubMed]

106. Koller, G.; Berkebile, S.; Krenn, J.R.; Netzer, F.P.; Oehzelt, M.; Haber, T.; Resel, R.; Ramsey, M.G. Heteroepitaxy of organic-organic nanostructures. Nano Lett. 2006, 6, 1207-1212. [CrossRef] [PubMed]

107. Srivastava, S.; Kotov, N.A. Composite Layer-by-Layer (LBL) assembly with inorganic nanoparticles and nanowires. Acc. Chem. Res. 2008, 41, 1831-1841. [CrossRef]

108. Minko, S. Responsive polymer brushes. Polym. Rev. 2006, 46, 397-420. [CrossRef]

109. Kim, W.; Jung, J. Polymer brush: A promising grafting approach to scaffolds for tissue engineering. BMB Rep. 2016, 49, 655-661. [CrossRef]

110. Neufurth, M.; Wang, X.; Wang, S.; Steffen, R.; Ackermann, M.; Haep, N.D.; Schröder, H.C.; Müller, W.E.G. 3D printing of hybrid biomaterials for bone tissue engineering: Calcium-polyphosphate microparticles encapsulated by polycaprolactone. Acta Biomater. 2017, 64, 377-388. [CrossRef]

111. Mondschein, R.J.; Kanitkar, A.; Williams, C.B.; Verbridge, S.S.; Long, T.E. Polymer structure-property requirements for stereolithographic 3D printing of soft tissue engineering scaffolds. Biomaterials 2017, 140, 170-188. [CrossRef] 
112. Tytgat, L.; Van Damme, L.; Ortega Arevalo, M.D.P.; Declercq, H.; Thienpont, H.; Otteveare, H.; Blondeel, P.; Dubruel, P.; Van Vlierberghe, S. Extrusion-based 3D printing of photo-crosslinkable gelatin and k-carrageenan hydrogel blends for adipose tissue regeneration. Int. J. Biol. Macromol. 2019, 140, 929-938. [CrossRef]

113. Jammalamadaka, U.; Tappa, K. Recent advances in biomaterials for 3D printing and tissue engineering. J. Funct. Biomater. 2018, 9, 22. [CrossRef]

114. Zhao, Q.; Wang, M. Smart Multifunctional Tissue Engineering Scaffolds; The Royal Society of Chemistry: London, UK, 2017; Volume 2017-Janua, ISBN 9781788010542.

115. Saha, K.; Keung, A.J.; Irwin, E.F.; Li, Y.; Little, L.; Schaffer, D.V.; Healy, K.E. Substrate modulus directs neural stem cell behavior. Biophys. J. 2008, 95, 4426-4438. [CrossRef] [PubMed]

116. Mano, J.F.; Silva, G.A.; Azevedo, H.S.; Malafaya, P.B.; Sousa, R.A.; Silva, S.S.; Boesel, L.F.; Oliveira, J.M.; Santos, T.C.; Marques, A.P.; et al. Natural origin biodegradable systems in tissue engineering and regenerative medicine: Present status and some moving trends. J. R. Soc. Interface 2007, 4, 999-1030. [CrossRef] [PubMed]

117. Gomes, S.; Leonor, I.B.; Mano, J.F.; Reis, R.L.; Kaplan, D.L. Natural and genetically engineered proteins for tissue engineering. Prog. Polym. Sci. 2012, 37, 1-17. [CrossRef] [PubMed]

118. Kim, D.-H.; Wong, P.K.; Park, J.; Levchenko, A.; Sun, Y. Microengineered Platforms for Cell Mechanobiology. Annu. Rev. Biomed. Eng. 2009, 11, 203-233. [CrossRef] [PubMed]

119. Mohiaddin, R.H. Assessment of the Biophysical Mechanical Properties of the Arterial Wall, 3rd ed.; Elsevier Inc.: Amsterdam, The Netherlands, 2010.

120. Lee, H.; Bellamkonda, R.V.; Sun, W.; Levenston, M.E. Biomechanical analysis of silicon microelectrode-induced strain in the brain. J. Neural Eng. 2005, 2, 81-89. [CrossRef] [PubMed]

121. Samani, A.; Zubovits, J.; Plewes, D. Elastic moduli of normal and pathological human breast tissues: An inversion-technique-based investigation of 169 samples. Phys. Med. Biol. 2007, 52, 1565-1576. [CrossRef]

122. Mow, V.C.; Holmes, M.H.; Michael Lai, W. Fluid transport and mechanical properties of articular cartilage: A review. J. Biomech. 1984, 17, 377-394. [CrossRef]

123. Ariza-Gracia, M.Á.; Redondo, S.; Piñero Llorens, D.; Calvo, B.; Rodriguez Matas, J.F. A predictive tool for determining patient-specific mechanical properties of human corneal tissue. Comput. Methods Appl. Mech. Eng. 2017, 317, 226-247. [CrossRef]

124. Madhurapantula, R.S.; Krell, G.; Morfin, B.; Roy, R.; Lister, K.; Orgel, J.P.R.O. Advanced methodology and preliminary measurements of molecular and mechanical properties of heart valves under dynamic strain. Int. J. Mol. Sci. 2020, 21, 763. [CrossRef]

125. Dittmann, F.; Tzschätzsch, H.; Hirsch, S.; Barnhill, E.; Braun, J.; Sack, I.; Guo, J. Tomoelastography of the abdomen: Tissue mechanical properties of the liver, spleen, kidney, and pancreas from single MR elastography scans at different hydration states. Magn. Reson. Med. 2017, 78, 976-983. [CrossRef]

126. Cecilia, A.; Baecker, A.; Hamann, E.; Rack, A.; van de Kamp, T.; Gruhl, F.J.; Hofmann, R.; Moosmann, J.; Hahn, S.; Kashef, J.; et al. Optimizing structural and mechanical properties of cryogel scaffolds for use in prostate cancer cell culturing. Mater. Sci. Eng. C 2017, 71, 465-472. [CrossRef] [PubMed]

127. Abé, H.; Hayashi, K.; Sato, M. (Eds.) Data Book on Mechanical Properties of Living Cells, Tissues, and Organs; Springer: Japan, Tokyo, 1996; ISBN 978-4-431-65864-1.

128. Kjær, M. Role of Extracellular Matrix in Adaptation of Tendon and Skeletal Muscle to Mechanical Loading. Physiol. Rev. 2004, 84, 649-698. [CrossRef] [PubMed]

129. Oyen, M.L. Mechanical characterisation of hydrogel materials. Int. Mater. Rev. 2014, 59, 44-59. [CrossRef]

130. Michler, G.H.; Baltá-Calleja, F.J. (Eds.) Mechanical Properties of Polymers Based on Nanostructure and Morphology; CRC Press: Boca Raton, FL, USA, 2016; ISBN 9781420027136.

131. Kim, H.N.; Kang, D.H.; Kim, M.S.; Jiao, A.; Kim, D.H.; Suh, K.Y. Patterning methods for polymers in cell and tissue engineering. Ann. Biomed. Eng. 2012, 40, 1339-1355. [CrossRef]

132. Nemir, S.; West, J.L. Synthetic materials in the study of cell response to substrate rigidity. Ann. Biomed. Eng. 2010, 38, 2-20. [CrossRef]

133. Robinson, P.S.; Huang, T.F.; Kazam, E.; Iozzo, R.V.; Birk, D.E.; Soslowsky, L.J. Influence of decorin and biglycan on mechanical properties of multiple tendons in knockout mice. J. Biomech. Eng. 2005, 127, 181-185. [CrossRef]

134. Levental, I.; Georges, P.C.; Janmey, P.A. Soft biological materials and their impact on cell function. Soft Matter 2007, 3, 299-306. [CrossRef] 
135. Bölgen, N. Electrospun materials for bone and tendon/ligament tissue engineering. In Electrospun Materials for Tissue Engineering and Biomedical Applications: Research, Design and Commercialization; Elsevier: Amsterdam, The Netherlands, 2017; pp. 233-260, ISBN 978008102222.

136. Webb, W.R.; Dale, T.P.; Lomas, A.J.; Zeng, G.; Wimpenny, I.; El Haj, A.J.; Forsyth, N.R.; Chen, G.Q. The application of poly(3-hydroxybutyrate-co-3-hydroxyhexanoate) scaffolds for tendon repair in the rat model. Biomaterials 2013, 34, 6683-6694. [CrossRef]

137. Prabhakaran, M.P.; Venugopal, J.; Ramakrishna, S. Electrospun nanostructured scaffolds for bone tissue engineering. Acta Biomater. 2009, 5, 2884-2893. [CrossRef]

138. Saveleva, M.S.; Ivanov, A.N.; Kurtukova, M.O.; Atkin, V.S.; Ivanova, A.G.; Lyubun, G.P.; Martyukova, A.V.; Cherevko, E.I.; Sargsyan, A.K.; Fedonnikov, A.S.; et al. Hybrid PCL/CaCO 3 scaffolds with capabilities of carrying biologically active molecules: Synthesis, loading and in vivo applications. Mater. Sci. Eng. C 2018, 85, 57-67. [CrossRef]

139. Bergfelt, D.R. Anatomy and Physiology of the Mare. In Equine Breeding Management and Artificial Insemination; Elsevier: Amsterdam, The Netherlands, 2009; pp. 113-131, ISBN 9781416052340.

140. Herskovitz, I.; Macquhae, F.; Fox, J.D.; Kirsner, R.S. Skin movement, wound repair and development of engineered skin. Exp. Dermatol. 2016, 25, 99-100. [CrossRef] [PubMed]

141. Wong, R.; Geyer, S.; Weninger, W.; Guimberteau, J.C.; Wong, J.K. The dynamic anatomy and patterning of skin. Exp. Dermatol. 2016, 25, 92-98. [CrossRef]

142. Lee, K.; Silva, E.A.; Mooney, D.J. Growth factor delivery-based tissue engineering: General approaches and a review of recent developments. J. R. Soc. Interface 2011, 8, 153-170. [CrossRef] [PubMed]

143. Yesildag, C.; Ouyang, Z.; Zhang, Z.; Lensen, M.C. Micro-patterning of PEG-based hydrogels with gold nanoparticles using a reactive micro-contact-printing approach. Front. Chem. 2019, 7. [CrossRef] [PubMed]

144. Lee, M.S.; Ahmad, T.; Lee, J.; Awada, H.K.; Wang, Y.; Kim, K.; Shin, H.; Yang, H.S. Dual delivery of growth factors with coacervate-coated poly(lactic-co-glycolic acid) nanofiber improves neovascularization in a mouse skin flap model. Biomaterials 2017, 124, 65-77. [CrossRef] [PubMed]

145. Dhandayuthapani, B.; Krishnan, U.M.; Sethuraman, S. Fabrication and characterization of chitosan-gelatin blend nanofibers for skin tissue engineering. J. Biomed. Mater. Res. Part B Appl. Biomater. 2010, 94, $264-272$. [CrossRef] [PubMed]

146. Gümüşderelioglu, M.; Dalkiranoglu, S.; Aydin, R.S.T.; Çakmak, S. A novel dermal substitute based on biofunctionalized electrospun PCL nanofibrous matrix. J. Biomed. Mater. Res. Part A 2011, 98, 461-472.

147. Tigli, R.S.; Kazaroglu, N.M.; Maviş, B.; Gumusderelioglu, M. Cellular behavior on epidermal growth factor (EGF)-immobilized PCL/gelatin nanofibrous scaffolds. J. Biomater. Sci. Polym. Ed. 2011, 22, 207-223. [CrossRef]

148. Albright, V.; Xu, M.; Palanisamy, A.; Cheng, J.; Stack, M.; Zhang, B.; Jayaraman, A.; Sukhishvili, S.A.; Wang, H. Micelle-Coated, Hierarchically Structured Nanofibers with Dual-Release Capability for Accelerated Wound Healing and Infection Control. Adv. Healthc. Mater. 2018, 7, 1800132. [CrossRef]

149. Kaur, P.; Gondil, V.S.; Chhibber, S. A novel wound dressing consisting of PVA-SA hybrid hydrogel membrane for topical delivery of bacteriophages and antibiotics. Int. J. Pharm. 2019, 572, 118779. [CrossRef]

150. Dong, G.; Liu, H.; Yu, X.; Zhang, X.; Lu, H.; Zhou, T.; Cao, J. Antimicrobial and anti-biofilm activity of tannic acid against Staphylococcus aureus. Nat. Prod. Res. 2018, 32, 2225-2228. [CrossRef] [PubMed]

151. Jung, M.K.; Hur, D.Y.; Song, S.B.; Park, Y.; Kim, T.S.; Bang, S.I.; Kim, S.; Song, H.K.; Park, H.; Cho, D.H. Tannic acid and quercetin display a therapeutic effect in atopic dermatitis via suppression of angiogenesis and TARC expression in Nc/Nga mice. J. Investig. Dermatol. 2010, 130, 1459-1463. [CrossRef] [PubMed]

152. Park, U.; Kim, K. Multiple growth factor delivery for skin tissue engineering applications. Biotechnol. Bioprocess Eng. 2017, 22, 659-670. [CrossRef]

153. Ribeiro, M.P.; Morgado, P.I.; Miguel, S.P.; Coutinho, P.; Correia, I.J. Dextran-based hydrogel containing chitosan microparticles loaded with growth factors to be used in wound healing. Mater. Sci. Eng. C 2013, 33, 2958-2966. [CrossRef] [PubMed]

154. Zhang, H.; Lui, K.O.; Zhou, B. Endocardial cell plasticity in cardiac development, diseases and regeneration. Circ. Res. 2018, 122, 774-789. [CrossRef] [PubMed]

155. Kennedy, S.; Touyz, R.M. Anatomy and Pharmacology of Vessels. In Textbook of Vascular Medicine; Springer International Publishing: Cham, Switzerland, 2019; pp. 3-11. 
156. Van Hinsbergh, V.W.M. Physiology of Blood Vessels; Krams, R., Bäck, M., Eds.; Oxford University Press: Oxford, UK, 2017; Volume 1, ISBN 9780198755777.

157. Famaey, N.; Verhoeven, J.; Jacobs, S.; Pettinari, M.; Meyns, B. In situ evolution of the mechanical properties of stretchable and non-stretchable ePTFE vascular grafts and adjacent native vessels. Int. J. Artif. Organs 2014, 37, 900-910. [CrossRef]

158. Tsuneki, M.; Hardee, S.; Michaud, M.; Morotti, R.; Lavik, E.; Madri, J.A. A hydrogel-endothelial cell implant mimics infantile hemangioma: Modulation by survivin and the Hippo pathway. Lab. Investig. 2015, 95, 765-780. [CrossRef]

159. Moulisová, V.; Gonzalez-García, C.; Cantini, M.; Rodrigo-Navarro, A.; Weaver, J.; Costell, M.; i Serra, R.S.; Dalby, M.J.; García, A.J.; Salmerón-Sánchez, M. Engineered microenvironments for synergistic VEGF-Integrin signalling during vascularization. Biomaterials 2017, 126, 61-74. [CrossRef]

160. Fitch, M.T.; Silver, J. CNS injury, glial scars, and inflammation: Inhibitory extracellular matrices and regeneration failure. Exp. Neurol. 2008, 209, 294-301. [CrossRef]

161. Arslantunali, D.; Dursun, T.; Yucel, D.; Hasirci, N.; Hasirci, V. Peripheral nerve conduits: Technology update. Med. Devices Evid. Res. 2014, 7, 405-424.

162. Cirillo, V.; Clements, B.A.; Guarino, V.; Bushman, J.; Kohn, J.; Ambrosio, L. A comparison of the performance of mono- and bi-component electrospun conduits in a rat sciatic model. Biomaterials 2014, 35, 8970-8982. [CrossRef] [PubMed]

163. Zhao, Y.Z.; Jiang, X.; Xiao, J.; Lin, Q.; Yu, W.Z.; Tian, F.R.; Mao, K.L.; Yang, W.; Wong, H.L.; Lu, C.T. Using NGF heparin-poloxamer thermosensitive hydrogels to enhance the nerve regeneration for spinal cord injury. Acta Biomater. 2016, 29, 71-80. [CrossRef] [PubMed]

164. Burdick, J.A.; Ward, M.; Liang, E.; Young, M.J.; Langer, R. Stimulation of neurite outgrowth by neurotrophins delivered from degradable hydrogels. Biomaterials 2006, 27, 452-459. [CrossRef] [PubMed]

165. Stanwick, J.C.; Baumann, M.D.; Shoichet, M.S. Enhanced neurotrophin-3 bioactivity and release from a nanoparticle-loaded composite hydrogel. J. Control. Release 2012, 160, 666-675. [CrossRef]

166. Ghosh, B.; Wang, Z.; Nong, J.; Urban, M.W.; Zhang, Z.; Trovillion, V.A.; Wright, M.C.; Zhong, Y.; Lepore, A.C. Local BDNF delivery to the injured cervical spinal cord using an engineered hydrogel enhances diaphragmatic respiratory function. J. Neurosci. 2018, 38, 5982-5995. [CrossRef]

167. Wylie, R.G.; Ahsan, S.; Aizawa, Y.; Maxwell, K.L.; Morshead, C.M.; Shoichet, M.S. Spatially controlled simultaneous patterning of multiple growth factors in three-dimensional hydrogels. Nat. Mater. 2011, 10, 799-806. [CrossRef]

168. Aizawa, Y.; Wylie, R.; Shoichet, M. Endothelial Cell Guidance in 3D Patterned Scaffolds. Adv. Mater. 2010, 22, 4831-4835. [CrossRef]

169. Owen, S.C.; Fisher, S.A.; Tam, R.Y.; Nimmo, C.M.; Shoichet, M.S. Hyaluronic acid click hydrogels emulate the extracellular matrix. Langmuir 2013, 29, 7393-7400. [CrossRef]

170. Martino, M.M.; Tortelli, F.; Mochizuki, M.; Traub, S.; Ben-David, D.; Kuhn, G.A.; Müller, R.; Livne, E.; Eming, S.A.; Hubbell, J.A. Engineering the growth factor microenvironment with fibronectin domains to promote wound and bone tissue healing. Sci. Transl. Med. 2011, 3, 100ra89. [CrossRef]

171. Park, S.Y.; Choi, D.S.; Jin, H.J.; Park, J.; Byun, K.E.; Lee, K.B.; Hong, S. Polarization-controlled differentiation of human neural stem cells using synergistic cues from the patterns of carbon nanotube monolayer coating. ACS Nano 2011, 5, 4704-4711. [CrossRef]

172. de Ruiter, G.C.W.; Malessy, M.J.A.; Yaszemski, M.J.; Windebank, A.J.; Spinner, R.J. Designing ideal conduits for peripheral nerve repair. Neurosurg. Focus 2009, 26, 1-9. [CrossRef] [PubMed]

173. Pillay, V.; Murugan, K.; Choonara, Y.E.; Kumar, P.; Bijukumar, D.; du Toit, L.C. Parameters and characteristics governing cellular internalization and trans-barrier trafficking of nanostructures. Int. J. Nanomed. 2015, 2191.

174. Bawa, P.; Pillay, V.; Choonara, Y.E.; Du Toit, L.C. Stimuli-responsive polymers and their applications in drug delivery. Biomed. Mater. 2009, 4, 022001. [CrossRef] [PubMed]

175. Tebyanian, H.; Karami, A.; Nourani, M.R.; Motavallian, E.; Barkhordari, A.; Yazdanian, M.; Seifalian, A. Lung tissue engineering: An update. J. Cell. Physiol. 2019, 234, 19256-19270. [CrossRef]

176. Asselin-Labat, M.L.; Filby, C.E. Adult lung stem cells and their contribution to lung tumourigenesis. Open Biol. 2012, 2, 120094. [CrossRef]

177. Tsukada, H.; Gangadharan, S.; Garland, R.; Herth, F.; Decamp, M.; Ernst, A. Tracheal replacement with a bioabsorbable scaffold in sheep. Ann. Thorac. Surg. 2010, 90, 1793-1797. [CrossRef] 
178. Higuita-Castro, N.; Nelson, M.T.; Shukla, V.; Agudelo-Garcia, P.A.; Zhang, W.; Duarte-Sanmiguel, S.M.; Englert, J.A.; Lannutti, J.J.; Hansford, D.J.; Ghadiali, S.N. Using a Novel Microfabricated Model of the Alveolar-Capillary Barrier to Investigate the Effect of Matrix Structure on Atelectrauma. Sci. Rep. 2017, 7, 1-13. [CrossRef]

179. Willig, S.P. Kidney anatomy and physiology. In Biomedical Instrumentation E Technology/Association for the Advancement of Medical Instrumentation; Springer International Publishing: Cham, Switzerland, 1993; Volume 27, pp. 342-344.

180. Ratliff, B.B.; Ghaly, T.; Brudnicki, P.; Yasuda, K.; Rajdev, M.; Bank, M.; Mares, J.; Hatzopoulos, A.K.; Goligorsky, M.S. Endothelial progenitors encapsulated in bioartificial niches are insulated from systemic cytotoxicity and are angiogenesis competent. Am. J. Physiol. Ren. Physiol. 2010, 299, F178-F186. [CrossRef]

181. McFetridge, M.L.; Del Borgo, M.P.; Aguilar, M.I.; Ricardo, S.D. The use of hydrogels for cell-based treatment of chronic kidney disease. Clin. Sci. 2018, 132, 1977-1994. [CrossRef]

182. Ghaly, T.; Rabadi, M.M.; Weber, M.; Rabadi, S.M.; Bank, M.; Grom, J.M.; Fallon, J.T.; Goligorsky, M.S.; Ratliff, B.B. Hydrogel-embedded endothelial progenitor cells evade LPS and mitigate endotoxemia. Am. J. Physiol. Ren. Physiol. 2011, 301, F802-F812. [CrossRef]

183. Zullo, J.A.; Nadel, E.P.; Rabadi, M.M.; Baskind, M.J.; Rajdev, M.A.; Demaree, C.M.; Vasko, R.; Chugh, S.S.; Lamba, R.; Goligorsky, M.S.; et al. The Secretome of Hydrogel-Coembedded Endothelial Progenitor Cells and Mesenchymal Stem Cells Instructs Macrophage Polarization in Endotoxemia. Stem Cells Transl. Med. 2015, 4, 852-861. [CrossRef] [PubMed]

184. Feng, G.; Zhang, J.; Li, Y.; Nie, Y.; Zhu, D.; Wang, R.; Liu, J.; Gao, J.; Liu, N.; He, N.; et al. IGF-1 C domain-modified hydrogel enhances cell therapy for AKI. J. Am. Soc. Nephrol. 2016, 27, 2357-2369. [CrossRef] [PubMed]

185. Caldas, H.C.; Fernandes, I.M.M.; Kawasaki-Oyama, R.S.; Baptista, M.A.S.F.; Plepis, A.M.G.; Martins, V.A.; Coimbra, T.M.; Goloni-Bertollo, E.M.; Braile, D.M.; Abbud-Filho, M. Effect of stem cells seeded onto biomaterial on the progression of experimental chronic kidney disease. Exp. Biol. Med. 2011, 236, 746-754. [CrossRef] [PubMed]

186. Lih, E.; Park, W.; Park, K.W.; Chun, S.Y.; Kim, H.; Joung, Y.K.; Kwon, T.G.; Hubbell, J.A.; Han, D.K. A Bioinspired Scaffold with Anti-Inflammatory Magnesium Hydroxide and Decellularized Extracellular Matrix for Renal Tissue Regeneration. ACS Cent. Sci. 2019, 5, 458-467. [CrossRef] [PubMed]

187. Miya, M.; Maeshima, A.; Mishima, K.; Sakurai, N.; Ikeuchi, H.; Kuroiwa, T.; Hiromura, K.; Yokoo, H.; Nojima, Y. Enhancement of in vitro human tubulogenesis by endothelial cell-derived factors: Implications for in vivo tubular regeneration after injury. Am. J. Physiol. Ren. Physiol. 2011, 301, F387-F395. [CrossRef] [PubMed]

188. Milici, A.J.; Furie, M.B.; Carley, W.W. The formation of fenestrations and channels by capillary endothelium in vitro. Proc. Natl. Acad. Sci. USA 1985, 82, 6181-6185. [CrossRef]

189. Moon, K.H.; Ko, I.K.; Yoo, J.J.; Atala, A. Kidney diseases and tissue engineering. Methods 2016, 99, 112-119. [CrossRef]

190. Bhatia, S.N.; Underhill, G.H.; Zaret, K.S.; Fox, I.J. Cell and tissue engineering for liver disease. Sci. Transl. Med. 2014, 6, 245sr2. [CrossRef]

191. Palakkan, A.A.; Hay, D.C.; Pr, A.K.; Tv, K.; Ross, J.A. Liver tissue engineering and cell sources: Issues and challenges. Liver Int. 2013, 33, 666-676. [CrossRef]

192. Oe, S.; Fukunaka, Y.; Hirose, T.; Yamaoka, Y.; Tabata, Y. A trial on regeneration therapy of rat liver cirrhosis by controlled release of hepatocyte growth factor. J. Control. Release 2003, 88, 193-200. [CrossRef]

193. Tayalia, P.; Mooney, D.J. Controlled growth factor delivery for tissue engineering. Adv. Mater. 2009, 21, 3269-3285. [CrossRef] [PubMed]

194. Douglas, T.E.L.; Kumari, S.; Dziadek, K.; Dziadek, M.; Abalymov, A.; Cools, P.; Brackman, G.; Coenye, T.; Morent, R.; Mohan, M.K.; et al. Titanium surface functionalization with coatings of chitosan and polyphenol-rich plant extracts. Mater. Lett. 2017, 196, 213-216. [CrossRef]

195. Jain, E.; Damania, A.; Kumar, A. Biomaterials for liver tissue engineering. Hepatol. Int. 2014, 8, $185-197$. [CrossRef] [PubMed]

196. Carlisle, E.S.; Mariappan, M.R.; Nelson, K.D.; Thomes, B.E.; Timmons, R.B.; Constantinescu, A.; Eberhart, R.C.; Bankey, P.E. Enhancing hepatocyte adhesion by pulsed plasma deposition and polyethylene glycol coupling. Tissue Eng. 2000, 6, 45-52. [CrossRef] [PubMed] 
197. Lee, H.J.; Son, M.J.; Ahn, J.; Oh, S.J.; Lee, M.; Kim, A.; Jeung, Y.J.; Kim, H.G.; Won, M.; Lim, J.H.; et al. Elasticity-based development of functionally enhanced multicellular 3D liver encapsulated in hybrid hydrogel. Acta Biomater. 2017, 64, 67-79. [CrossRef] [PubMed]

198. Du, Y.; Han, R.; Wen, F.; Ng San San, S.; Xia, L.; Wohland, T.; Leo, H.L.; Yu, H. Synthetic sandwich culture of 3D hepatocyte monolayer. Biomaterials 2008, 29, 290-301. [CrossRef] [PubMed]

199. Qiu, Y.; Mao, Z.; Zhao, Y.; Zhang, J.; Guo, Q.; Gou, Z.; Gao, C. Polycaprolactone scaffold modified with galactosylated chitosan for hepatocyte culture. Macromol. Res. 2012, 20, 283-291. [CrossRef]

200. Rossi, C.A.; Pozzobon, M.; De Coppi, P. Advances in musculoskeletal tissue engineering: Moving towards therapy. Organogenesis 2010, 6, 167-172. [CrossRef]

201. Hahn, M.S.; Miller, J.S.; West, J.L. Three-dimensional biochemical and biomechanical patterning of hydrogels for guiding cell behavior. Adv. Mater. 2006, 18, 2679-2684. [CrossRef]

202. Wosnick, J.H.; Shoichet, M.S. Three-dimensional chemical patterning of transparent hydrogels. Chem. Mater. 2008, 20, 55-60. [CrossRef]

203. Lutolf, M.P.; Hubbell, J.A. Synthetic biomaterials as instructive extracellular microenvironments for morphogenesis in tissue engineering. Nat. Biotechnol. 2005, 23, 47-55. [CrossRef] [PubMed]

204. Roger, V.L.; Go, A.S.; Lloyd-Jones, D.M.; Benjamin, E.J.; Berry, J.D.; Borden, W.B.; Bravata, D.M.; Dai, S.; Ford, E.S.; Fox, C.S.; et al. Heart disease and stroke statistics-2012 update: A report from the American heart association. Circulation 2012, 125.

205. Chen, Q.-Z.; Harding, S.E.; Ali, N.N.; Lyon, A.R.; Boccaccini, A.R. Biomaterials in cardiac tissue engineering: Ten years of research survey. Mater. Sci. Eng. R Rep. 2008, 59, 1-37. [CrossRef]

206. Eng, G.; Lee, B.W.; Radisic, M.; Vunjak-Novakovic, G. Cardiac Tissue Engineering. In Principles of Tissue Engineering, 4th ed.; Elsevier: Amsterdam, The Netherlands, 2013; pp. 771-792, ISBN 9780123983589.

207. Ifkovits, J.L.; Devlin, J.J.; Eng, G.; Martens, T.P.; Vunjak-Novakovic, G.; Burdick, J.A. Biodegradable fibrous scaffolds with tunable properties formed from photo-cross-linkable poly(glycerol sebacate). ACS Appl. Mater. Interfaces 2009, 1, 1878-1886. [CrossRef]

208. Chen, Q.Z.; Ishii, H.; Thouas, G.A.; Lyon, A.R.; Wright, J.S.; Blaker, J.J.; Chrzanowski, W.; Boccaccini, A.R.; Ali, N.N.; Knowles, J.C.; et al. An elastomeric patch derived from poly(glycerol sebacate) for delivery of embryonic stem cells to the heart. Biomaterials 2010, 31, 3885-3893. [CrossRef]

209. Shandalov, Y.; Egozi, D.; Koffler, J.; Dado-Rosenfeld, D.; Ben-Shimol, D.; Freiman, A.; Shor, E.; Kabala, A.; Levenberg, S. An engineered muscle flap for reconstruction of large soft tissue defects. Proc. Natl. Acad. Sci. USA 2014, 111, 6010-6015. [CrossRef]

210. Wang, L.; Shansky, J.; Vandenburgh, H. Induced formation and maturation of acetylcholine receptor clusters in a defined 3D bio-artificial muscle. Mol. Neurobiol. 2013, 48, 397-403. [CrossRef]

211. Ko, I.K.; Lee, B.K.; Lee, S.J.; Andersson, K.E.; Atala, A.; Yoo, J.J. The effect of in vitro formation of acetylcholine receptor (AChR) clusters in engineered muscle fibers on subsequent innervation of constructs in vivo. Biomaterials 2013, 34, 3246-3255. [CrossRef]

212. Morimoto, Y.; Kato-Negishi, M.; Onoe, H.; Takeuchi, S. Three-dimensional neuron-muscle constructs with neuromuscular junctions. Biomaterials 2013, 34, 9413-9419. [CrossRef]

213. Juhas, M.; Engelmayr, G.C.; Fontanella, A.N.; Palmer, G.M.; Bursac, N. Biomimetic engineered muscle with capacity for vascular integration and functional maturation in vivo. Proc. Natl. Acad. Sci. USA 2014, 111, 5508-5513. [CrossRef]

214. Bernhard, M.; Waldner, M.; Plank, P.; Solteszova, V.; Viola, I. The Accuracy of Gauge-Figure Tasks in Monoscopic and Stereo Displays. IEEE Comput. Graph. Appl. 2016, 36, 56-66. [CrossRef] [PubMed]

215. Spiller, K.L.; Maher, S.A.; Lowman, A.M. Hydrogels for the repair of articular cartilage defects. Tissue Eng. Part B Rev. 2011, 17, 281-299. [CrossRef] [PubMed]

216. Oliveira, J.T.; Martins, L.; Picciochi, R.; Malafaya, P.B.; Sousa, R.A.; Neves, N.M.; Mano, J.F.; Reis, R.L. Gellan gum: A new biomaterial for cartilage tissue engineering applications. J. Biomed. Mater. Res. Part A 2010, 93, 852-863. [CrossRef] [PubMed]

217. Neves, S.C.; Moreira Teixeira, L.S.; Moroni, L.; Reis, R.L.; Van Blitterswijk, C.A.; Alves, N.M.; Karperien, M.; Mano, J.F. Chitosan/Poly( $\varepsilon$-caprolactone) blend scaffolds for cartilage repair. Biomaterials 2011, 32, 1068-1079. [CrossRef]

218. Cushing, M.C.; Anseth, K.S. Hydrogel cell cultures. Science (80-) 2007, 316, 1133-1134. [CrossRef] 
219. Sharma, B.; Williams, C.G.; Khan, M.; Manson, P.; Elisseeff, J.H. In vivo chondrogenesis of mesenchymal stem cells in a photopolymerized hydrogel. Plast. Reconstr. Surg. 2007, 119, 112-120. [CrossRef]

220. Rezwan, K.; Chen, Q.Z.; Blaker, J.J.; Boccaccini, A.R. Biodegradable and bioactive porous polymer/inorganic composite scaffolds for bone tissue engineering. Biomaterials 2006, 27, 3413-3431. [CrossRef]

221. Hu, C.; Ashok, D.; Nisbet, D.R.; Gautam, V. Bioinspired surface modification of orthopedic implants for bone tissue engineering. Biomaterials 2019, 219, 119366. [CrossRef]

222. Henkel, J.; Woodruff, M.A.; Epari, D.R.; Steck, R.; Glatt, V.; DIckinson, I.C.; Choong, P.F.M.; Schuetz, M.A.; Hutmacher, D.W. Bone Regeneration Based on Tissue Engineering Conceptions-A 21st Century Perspective. Bone Res. 2013, 1, 216-248. [CrossRef]

223. Holzwarth, J.M.; Ma, P.X. Biomimetic nanofibrous scaffolds for bone tissue engineering. Biomaterials 2011, 32, 9622-9629. [CrossRef]

224. Vaquette, C.; Ivanovski, S.; Hamlet, S.M.; Hutmacher, D.W. Effect of culture conditions and calcium phosphate coating on ectopic bone formation. Biomaterials 2013, 34, 5538-5551. [CrossRef] [PubMed]

225. Habibovic, P.; Sees, T.M.; Van Den Doel, M.A.; Van Blitterswijk, C.A.; De Groot, K. Osteoinduction by biomaterials-Physicochemical and structural influences. J. Biomed. Mater. Res. Part A 2006, 77, 747-762. [CrossRef] [PubMed]

226. Barradas, A.M.C.; Yuan, H.; van Blitterswijk, C.A.; Habibovic, P. Osteoinductive biomaterials: Current knowledge of properties, experimental models and biological mechanisms. Eur. Cells Mater. 2011, 21, 407-429. [CrossRef] [PubMed]

227. Chai, Y.C.; Carlier, A.; Bolander, J.; Roberts, S.J.; Geris, L.; Schrooten, J.; Van Oosterwyck, H.; Luyten, F.P. Current views on calcium phosphate osteogenicity and the translation into effective bone regeneration strategies. Acta Biomater. 2012, 8, 3876-3887. [CrossRef] [PubMed]

228. Muderrisoglu, C.; Saveleva, M.; Abalymov, A.; Van der Meeren, L.; Ivanova, A.; Atkin, V.; Parakhonskiy, B.; Skirtach, A.G. Nanostructured Biointerfaces Based on Bioceramic Calcium Carbonate/Hydrogel Coatings on Titanium with an Active Enzyme for Stimulating Osteoblasts Growth. Adv. Mater. Interfaces 2018, 5, 1800452. [CrossRef]

229. Saveleva, M.; Vladescu, A.; Cotrut, C.; Van Der Meeren, L.; Surmeneva, M.; Surmenev, R.; Parakhonskiy, B.; Skirtach, A.G. The effect of hybrid coatings based on hydrogel, biopolymer and inorganic components on the corrosion behavior of titanium bone implants. J. Mater. Chem. B 2019, 7, 6778-6788. [CrossRef]

230. Sheng, D.; Li, J.; Ai, C.; Feng, S.; Ying, T.; Liu, X.; Cai, J.; Ding, X.; Jin, W.; Xu, H.; et al. Electrospun PCL/Gel-aligned scaffolds enhance the biomechanical strength in tendon repair. J. Mater. Chem. B 2019, 7 , 4801-4810. [CrossRef]

231. Chen, X.; Qi, Y.Y.; Wang, L.L.; Yin, Z.; Yin, G.L.; Zou, X.H.; Ouyang, H.W. Ligament regeneration using a knitted silk scaffold combined with collagen matrix. Biomaterials 2008, 29, 3683-3692. [CrossRef]

232. Chen, J.L.; Yin, Z.; Shen, W.L.; Chen, X.; Heng, B.C.; Zou, X.H.; Ouyang, H.W. Efficacy of hESC-MSCs in knitted silk-collagen scaffold for tendon tissue engineering and their roles. Biomaterials 2010, 31, 9438-9451. [CrossRef]

233. Shen, W.; Chen, X.; Hu, Y.; Yin, Z.; Zhu, T.; Hu, J.; Chen, J.; Zheng, Z.; Zhang, W.; Ran, J.; et al. Long-term effects of knitted silk-collagen sponge scaffold on anterior cruciate ligament reconstruction and osteoarthritis prevention. Biomaterials 2014, 35, 8154-8163. [CrossRef]

234. Riedel, T.; Brynda, E.; Dyr, J.E.; Houska, M. Controlled preparation of thin fibrin films immobilized at solid surfaces. J. Biomed. Mater. Res. Part A 2009, 88, 437-447. [CrossRef] [PubMed]

235. Gray, J.L.; Kang, S.S.; Zenni, G.C.; Kim, D.U.; Kim, P.I.; Burgess, W.H.; Drohan, W.; Winkles, J.A.; Haudenschild, C.C.; Greisler, H.P. FGF-1 Affixation Stimulates ePTFE Endothelialization without Intimal Hyperplasia. J. Surg. Res. 1994, 57, 596-612. [CrossRef] [PubMed]

236. Li, C.; Hill, A.; Imran, M. In vitro and in vivo studies of ePTFE vascular grafts treated with P15 peptide. J. Biomater. Sci. Polym. Ed. 2005, 16, 875-891. [CrossRef] [PubMed]

237. Randone, B.; Cavallaro, G.; Polistena, A.; Cucina, A.; Coluccia, P.; Graziano, P.; Cavallaro, A. Dual role of VEGF in pretreated experimental ePTFE arterial grafts. J. Surg. Res. 2005, 127, 70-79. [CrossRef]

238. Li, X.; Cho, B.; Martin, R.; Seu, M.; Zhang, C.; Zhou, Z.; Choi, J.S.; Jiang, X.; Chen, L.; Walia, G.; et al. Nanofiber-hydrogel composite-mediated angiogenesis for soft tissue reconstruction. Sci. Transl. Med. 2019, 11,1-12. [CrossRef] 
239. Suzuki, M.; Itoh, S.; Yamaguchi, I.; Takakuda, K.; Kobayashi, H.; Shinomiya, K.; Tanaka, J. Tendon chitosan tubes covalently coupled with synthesized laminin peptides facilitate nerve regeneration in vivo. J. Neurosci. Res. 2003, 72, 646-659. [CrossRef]

240. Farzamfar, S.; Esmailpour, F.; Ebrahimi, E.; Vahedi, H.; Salehi, M. Poly-lactic Acid/Gelatin Nanofiber (PLA/GTNF) Conduits Containing Platelet-Rich Plasma for Peripheral Nerve Regeneration. Int. J. Health Stud. 2017, 3, 29-32.

241. Amado, S.; Simões, M.J.; Armada da Silva, P.A.S.; Luís, A.L.; Shirosaki, Y.; Lopes, M.A.; Santos, J.D.; Fregnan, F.; Gambarotta, G.; Raimondo, S.; et al. Use of hybrid chitosan membranes and N1E-115 cells for promoting nerve regeneration in an axonotmesis rat model. Biomaterials 2008, 29, 4409-4419. [CrossRef]

242. Haile, Y.; Berski, S.; Dräger, G.; Nobre, A.; Stummeyer, K.; Gerardy-Schahn, R.; Grothe, C. The effect of modified polysialic acid based hydrogels on the adhesion and viability of primary neurons and glial cells. Biomaterials 2008, 29, 1880-1891. [CrossRef]

243. Li, W.; Guo, Y.; Wang, H.; Shi, D.; Liang, C.; Ye, Z.; Qing, F.; Gong, J. Electrospun nanofibers immobilized with collagen for neural stem cells culture. J. Mater. Sci. Mater. Med. 2008, 19, 847-854. [CrossRef]

244. Xie, J.; MacEwcm, M.R.; Willerth, S.M.; Li, X.; Moran, D.W.; Sakiyama-Elbert, S.E.; Xia, Y. Conductive core-sheath nanofibers and their potential application in neural tissue engineering. Adv. Funct. Mater. 2009, 19, 2312-2318. [CrossRef] [PubMed]

245. Wang, T.Y.; Forsythe, J.S.; Parish, C.L.; Nisbet, D.R. Biofunctionalisation of polymeric scaffolds for neural tissue engineering. J. Biomater. Appl. 2012, 27, 369-390. [CrossRef] [PubMed]

246. Freudenberg, U.; Hermann, A.; Welzel, P.B.; Stirl, K.; Schwarz, S.C.; Grimmer, M.; Zieris, A.; Panyanuwat, W.; Zschoche, S.; Meinhold, D.; et al. A star-PEG-heparin hydrogel platform to aid cell replacement therapies for neurodegenerative diseases. Biomaterials 2009, 30, 5049-5060. [CrossRef] [PubMed]

247. Dodla, M.C.; Bellamkonda, R.V. Differences between the effect of anisotropic and isotropic laminin and nerve growth factor presenting scaffolds on nerve regeneration across long peripheral nerve gaps. Biomaterials 2008, 29, 33-46. [CrossRef] [PubMed]

248. Kosmala, A.; Fitzgerald, M.; Moore, E.; Stam, F. Evaluation of a Gelatin-Modified Poly( $\varepsilon$-Caprolactone) Film as a Scaffold for Lung Disease. Anal. Lett. 2017, 50, 219-232. [CrossRef]

249. Ramaswamy, S.; Gottlieb, D.; Engelmayr, G.C.; Aikawa, E.; Schmidt, D.E.; Gaitan-Leon, D.M.; Sales, V.L.; Mayer, J.E.; Sacks, M.S. The role of organ level conditioning on the promotion of engineered heart valve tissue development in-vitro using mesenchymal stem cells. Biomaterials 2010, 31, 1114-1125. [CrossRef]

250. Jansen, K.; Castilho, M.; Aarts, S.; Kaminski, M.M.; Lienkamp, S.S.; Pichler, R.; Malda, J.; Vermonden, T.; Jansen, J.; Masereeuw, R. Fabrication of Kidney Proximal Tubule Grafts Using Biofunctionalized Electrospun Polymer Scaffolds. Macromol. Biosci. 2019, 19, 1800412. [CrossRef]

251. Grant, R.; Hay, D.; Callanan, A. From scaffold to structure: The synthetic production of cell derived extracellular matrix for liver tissue engineering. Biomed. Phys. Eng. Express 2018, 4, 065015. [CrossRef]

252. Grant, R.; Hay, D.C.; Callanan, A. A Drug-Induced Hybrid Electrospun Poly-Capro-Lactone: Cell-Derived Extracellular Matrix Scaffold for Liver Tissue Engineering. Tissue Eng. Part A 2017, 23, 650-662. [CrossRef]

253. Wang, Y.; Liu, X.C.; Zhao, J.; Kong, X.R.; Shi, R.F.; Zhao, X.B.; Song, C.X.; Liu, T.J.; Lu, F. Degradable PLGA scaffolds with basic fibroblast growth factor: Experimental studies in myocardial revascularization. Tex. Heart Inst. J. 2009, 36, 89-97.

254. McDevitt, T.C.; Woodhouse, K.A.; Hauschka, S.D.; Murry, C.E.; Stayton, P.S. Spatially organized layers of cardiomyocytes on biodegradable polyurethane films for myocardial repair. J. Biomed. Mater. Res. Part A 2003, 66, 586-595. [CrossRef] [PubMed]

255. Koffler, J.; Kaufman-Francis, K.; Yulia, S.; Dana, E.; Daria, A.P.; Landesberg, A.; Levenberg, S. Improved vascular organization enhances functional integration of engineered skeletal muscle grafts. Proc. Natl. Acad. Sci. USA 2011, 108, 14789-14794. [CrossRef]

256. Sicari, B.M.; Peter Rubin, J.; Dearth, C.L.; Wolf, M.T.; Ambrosio, F.; Boninger, M.; Turner, N.J.; Weber, D.J.; Simpson, T.W.; Wyse, A.; et al. An acellular biologic scaffold promotes skeletal muscle formation in mice and humans with volumetric muscle loss. Sci. Transl. Med. 2014, 6, 234ra58. [CrossRef] [PubMed]

257. Boontheekul, T.; Hill, E.E.; Kong, H.-J.; Mooney, D.J. Regulating Myoblast Phenotype Through Controlled Gel Stiffness and Degradation. Tissue Eng. 2007, 13, 1431-1442. [CrossRef] [PubMed]

258. Smythe, G.M.; Hodgetts, S.I.; Grounds, M.D. Problems and solutions in myoblast transfer therapy. J. Cell. Mol. Med. 2001, 5, 33-47. [CrossRef] [PubMed] 
259. Hall, J.K.; Banks, G.B.; Chamberlain, J.S.; Olwin, B.B. Tissue engineering: Prevention of muscle aging by myofiber-associated satellite cell transplantation. Sci. Transl. Med. 2010, 2, 57ra83. [CrossRef]

260. Siclari, A.; Mascaro, G.; Gentili, C.; Cancedda, R.; Boux, E. A Cell-free scaffold-based cartilage repair provides improved function hyaline-like repair at one year. Clin. Orthop. Relat. Res. 2012, 470, 910-919. [CrossRef]

261. Jeuken, R.M.; Roth, A.K.; Peters, R.J.R.W.; van Donkelaar, C.C.; Thies, J.C.; van Rhijn, L.W.; Emans, P.J. Polymers in cartilage defect repair of the knee: Current status and future prospects. Polymers 2016, 8, 219. [CrossRef]

262. Moutos, F.T.; Freed, L.E.; Guilak, F. A biomimetic three-dimensional woven composite scaffold for functional tissue engineering of cartilage. Nat. Mater. 2007, 6, 162-167. [CrossRef]

263. Duarte Campos, D.F.; Drescher, W.; Rath, B.; Tingart, M.; Fischer, H. Supporting Biomaterials for Articular Cartilage Repair. Cartilage 2012, 3, 205-221. [CrossRef]

264. Yoon, D.M.; Curtiss, S.; Reddi, A.H.; Fisher, J.P. Addition of hyaluronic acid to alginate embedded chondrocytes interferes with insulin-like growth factor-1 signaling in vitro and in vivo. Tissue Eng. Part A 2009, 15, 3449-3459. [CrossRef] [PubMed]

265. Cui, W.; Wang, Q.; Chen, G.; Zhou, S.; Chang, Q.; Zuo, Q.; Ren, K.; Fan, W. Repair of articular cartilage defects with tissue-engineered osteochondral composites in pigs. J. Biosci. Bioeng. 2011, 111, 493-500. [CrossRef] [PubMed]

266. Chernozem, R.V.; Surmeneva, M.A.; Shkarina, S.N.; Loza, K.; Epple, M.; Ulbricht, M.; Cecilia, A.; Krause, B.; Baumbach, T.; Abalymov, A.A.; et al. Piezoelectric 3-D Fibrous Poly(3-hydroxybutyrate)-Based Scaffolds Ultrasound-Mineralized with Calcium Carbonate for Bone Tissue Engineering: Inorganic Phase Formation, Osteoblast Cell Adhesion, and Proliferation. ACS Appl. Mater. Interfaces 2019, 11, 19522-19533. [CrossRef] [PubMed]

(C) 2020 by the authors. Licensee MDPI, Basel, Switzerland. This article is an open access article distributed under the terms and conditions of the Creative Commons Attribution (CC BY) license (http://creativecommons.org/licenses/by/4.0/). 